\title{
Research on a Nationwide Area-Based Management Survey in Japan
}

\author{
By Jun Mitarai * \\ Naphasinee Suebsuk ${ }^{\dagger}$
}

\begin{abstract}
Japan is currently facing a population decrease, with low growth rates, financial constraints, and difficulty in maintaining its infrastructure. The way to revitalise the Japanese economy and improve the way of life does not merely involve development, but the efficient management of city resources. Therefore, Area-Based Management (ABM), defined as independent action to solve problems and enhance the value of a specific area by groups of residents, business owners, and landowners is now widespread in Japan. However, there are no surveys concerning the situation of ABM in Japan. Consequently, this nationwide ABM survey via questionnaire to local city governments was conducted in 2015 and 2016. The objective of this paper is to summarise a cognate field of ABM in Japan, involving objective, organisational structure, and activities. The survey identified at least 574 ABM organisations throughout Japan. The main objective of ABM is to create visitors, beautiful townscapes, community awareness, and networking. Approximately $70 \%$ of ABM organisations do not have juridical authority and $35 \%$ have been initiated by the public sector. ABM organisations obtain their revenue from government support, membership, and earnings generated from activities. Events provide the highest percentage from six categories of ABM activities, though this figure represents less than half of the $A B M$ organisation. The main issues for ABM involve finance and human resources. In conclusion, $A B M$ in Japan has various organisational structures and activities under three main objectives.
\end{abstract}

Keywords: area-based management, city management, public-private partnerships.

\section{Introduction}

ABM is defined as the independent action of a group of residents and business owners, landowners, etc., with the objective of improving and enhancing the environment and local lifestyles to provide value for the area, according to the Ministry of Land, Infrastructure, Transport and Tourism, Japan. In other words, its purpose is to revitalise the area enhancing the socio-economic aspects, etc. "Area" refers to a region on a smaller scale than city. It is similar size of a neighbourhood, community, or city centre. Japan's leading expert on ABM, Prof. Shigenori Kobayashi, provides a similar definition for "area management" as the Ministry of Land, Infrastructure, Transport and Tourism (Kobayashi 2005).

The concept of $\mathrm{ABM}$ is as follows: 1) to grow and improve as well as develop; 2) the residents, business owners, and landowners must be involved with

\footnotetext{
*Adjunct Professor, Graduate School of Management, Kyoto University, Japan.

${ }^{\dagger}$ Researcher, Urban Planner and Senior Project Coordinator, Magnolia Quality Development Corporation Limited, DTGO, Bangkok, Thailand.
} 
the work in addition to government but independently from government; 3) many residents, business owners and landowners must be involved; 4) a particular area is targeted.

Figure 1 shows the hierarchical structure of urban development and management. The top level of hierarchy is the country scale, followed by province or prefecture, and then city or village. At each of these three levels, the main player is the government. The bottom level is the individual scale, whereby the players are citizens, companies, etc., in other words, the building site scale. Between the individual and upper three government levels is the neighbourhood or community scale. ABM organisations are positioned at a similar level to traditional neighbourhood community associations and shop owner associations.

Figure 1. Hierarchical Structure of Urban Development and Management

Country scale

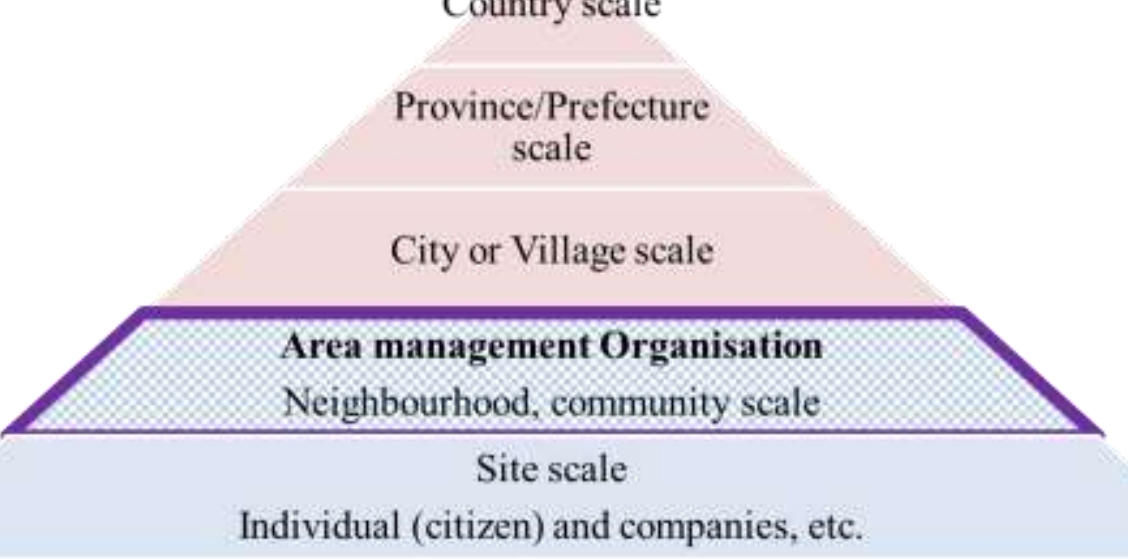

Recently, ABM has become more and more important for urban/regional rivitalisation and community development in Japan under the present social and economic situation as mentioned in "Present Social and Economic Situation in Japan (Needs of ABM)", and ABM is increasing. However, no one knows the whole picture of $A B M$ in Japan because there is currently no relevant nationwide survey of ABM in Japan.

Therefore, the objective of this research is to clarify the characteristics of $\mathrm{ABM}$ by investigating the actual comprehensive situation, focusing on the ABM objectives, establishment, activities, characteristics, effects, and problems with the first extensive nationwide survey of ABM in Japan. In addition, this paper offers suggestions and ideas for policies and further study of ABM in Japan or other countries wishing to introduce the system in the future.

\section{Background}




\section{Present Social and Economic Situation in Japan (Needs of ABM)}

Japan is currently experiencing a decrease in its population (Figure 2) as well as prolonged low growth rates (Figure 3), financial constraints and increase of national debt (Figure 4). Although the infrastructure is abundant (Figure 5), difficulties with the cost of its maintenance and improvement may become a huge problem for the country. Besides city development, management now plays an important role in cooperation between the public and private sectors due to the country's social and economic situation. It is therefore essential to grow and revitalise the economy, improve lifestyles and bring value to the area. Sustainability involves not development but the clever and effective use of today's available resources.

Figure 2. Population Trends in Japan

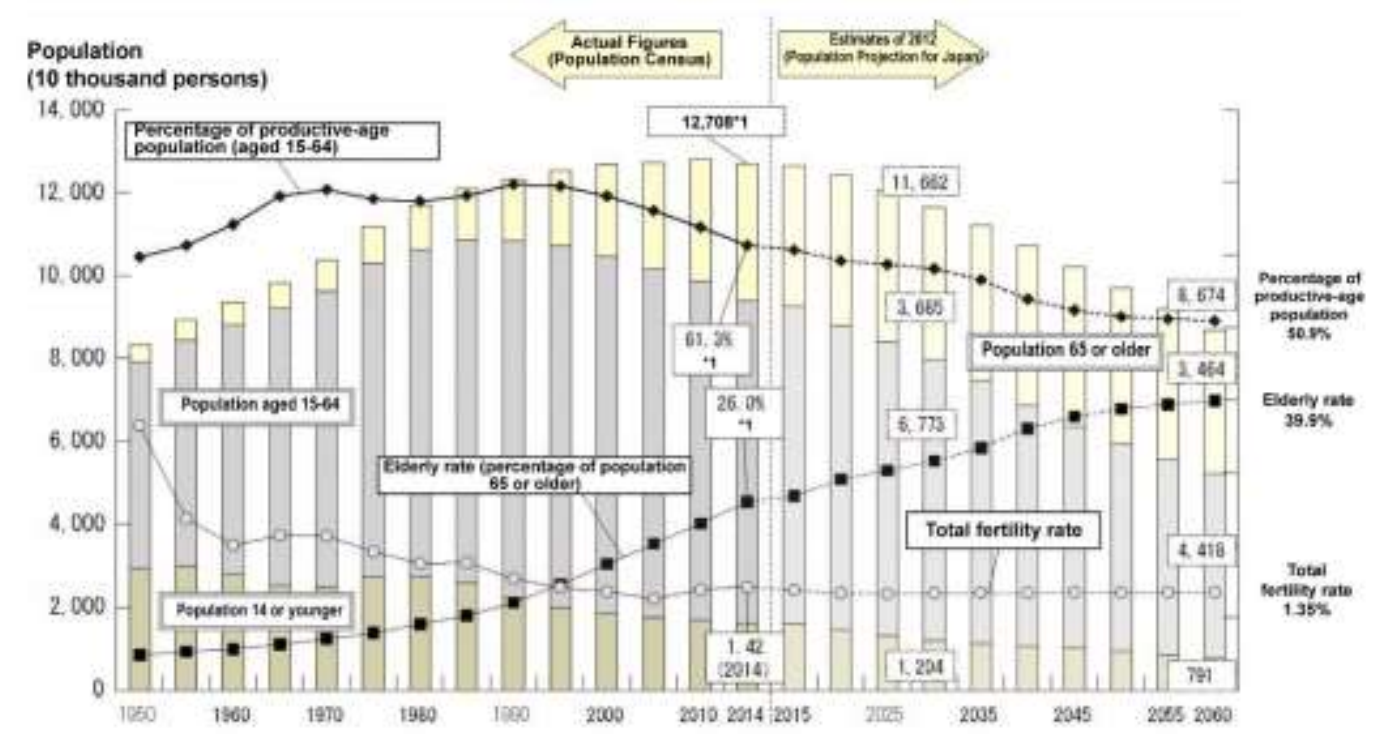

Source: Population Census' and 'Population Estimates' by the Statistics Bureau of the Ministry of Intemal Affairs and Communications, -Population Projection for Japan: Medium-Fertility/Mortality Projections (estimated in January 2012) by Mational institute of Population and Social Secunfy Research, (population as of October 1 of the respective year), "Vital Statistics" (2014 is preliminary data), MHLW/.

-1 Source: FY 2014. Population Estimates" by the Ministry of Internsi Affairs and Communications (according to the 2010 Population Census, the population was 128.06 million persons, the percentage of labor population was $63.8 \%$ and the aging rate was 23.0\%)

Source: Ministry of Health, Labour and Welfare, Japan 2015.

In essence, the effective use of the existing variety of infrastructure to coordinate the total urban space enterprise is extremely important. Moreover, it is necessary that the various persons involved combine their efforts to make full use of private sector influence and business management to enhance the uniqueness and characteristics of each area to correspond with community needs. These are the reasons why ABM is now drawing so much attention in Japan.

The primary role of $\mathrm{ABM}$ in growth and increased regional power involves the supply of public services to the city, not only as a local government alternative but also to complement between the public and private sectors. ABM also corresponds to the needs of the population by providing high-quality services for 
rule creation, facility management, or public service operation. The survival measures for regional competition in Japan at the present time focus on the uniqueness and characteristics of an area, and ABM is therefore very valuable. The effective size of public services units is usually smaller than that of local government, and consequently, the level of public services should be decided by the people in small areas, and ABM has an effective role to play in any decision. $\mathrm{ABM}$ is an appropriate method for minimising costs, generating revenue, or combining the public and private sector strong points. Finally, ABM helps incommunity rehabilitation, networking, and forming public consensus. In other words, it enhances social capital.

Figure 3. Annual Percentage GDP Growth in Japan

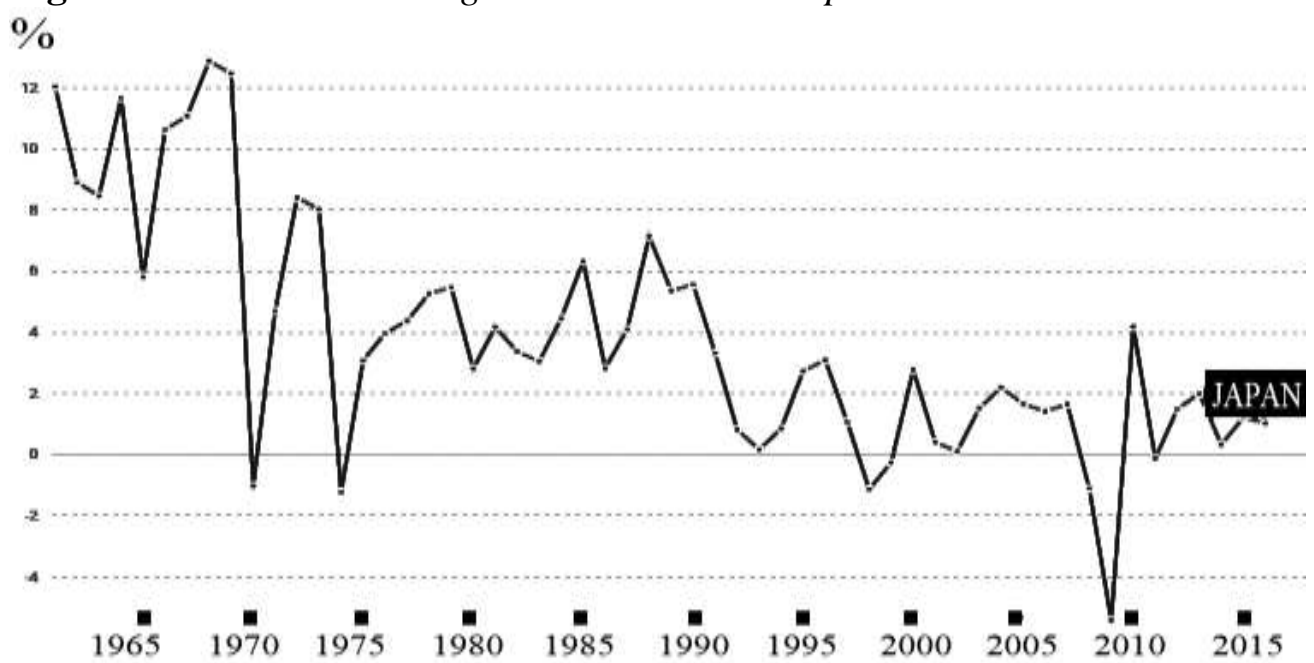

Source: The World Bank 2018. 
Figure 4. Outstanding Numberof Japanese General Bonds

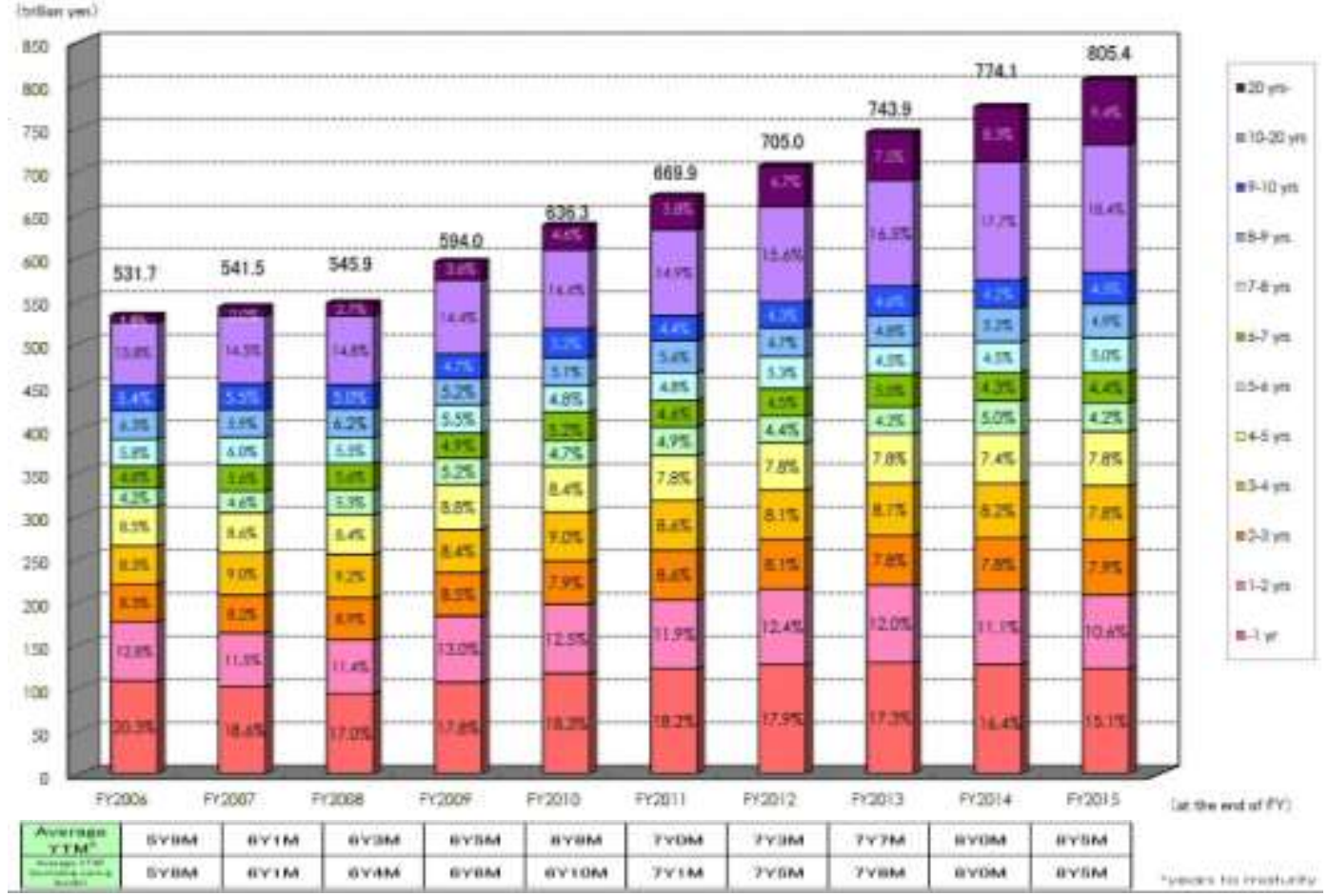

Source: Ministry of Finance, Japan 2017.

Figure 5. Dimensions and Budgets for City Parks in Japan

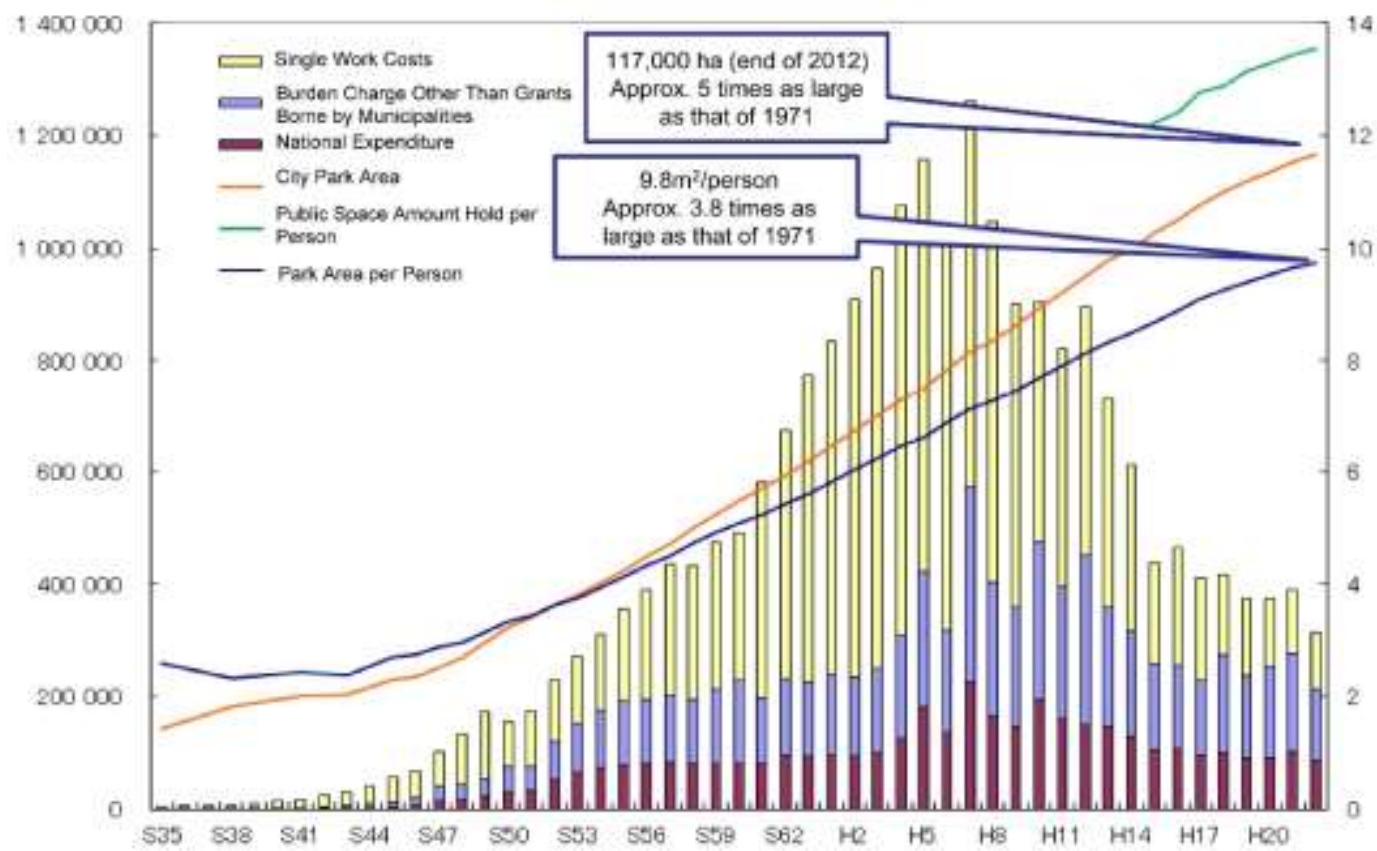

Source: Ministry of Land, Infrastructure, Transport and Tourism, Japan 2015.

Examples of ABM in Japan 


\section{Grand Front Osaka Town Management Organisation (TMO)}

Figure 6. Grand Front Osaka Area and Activities

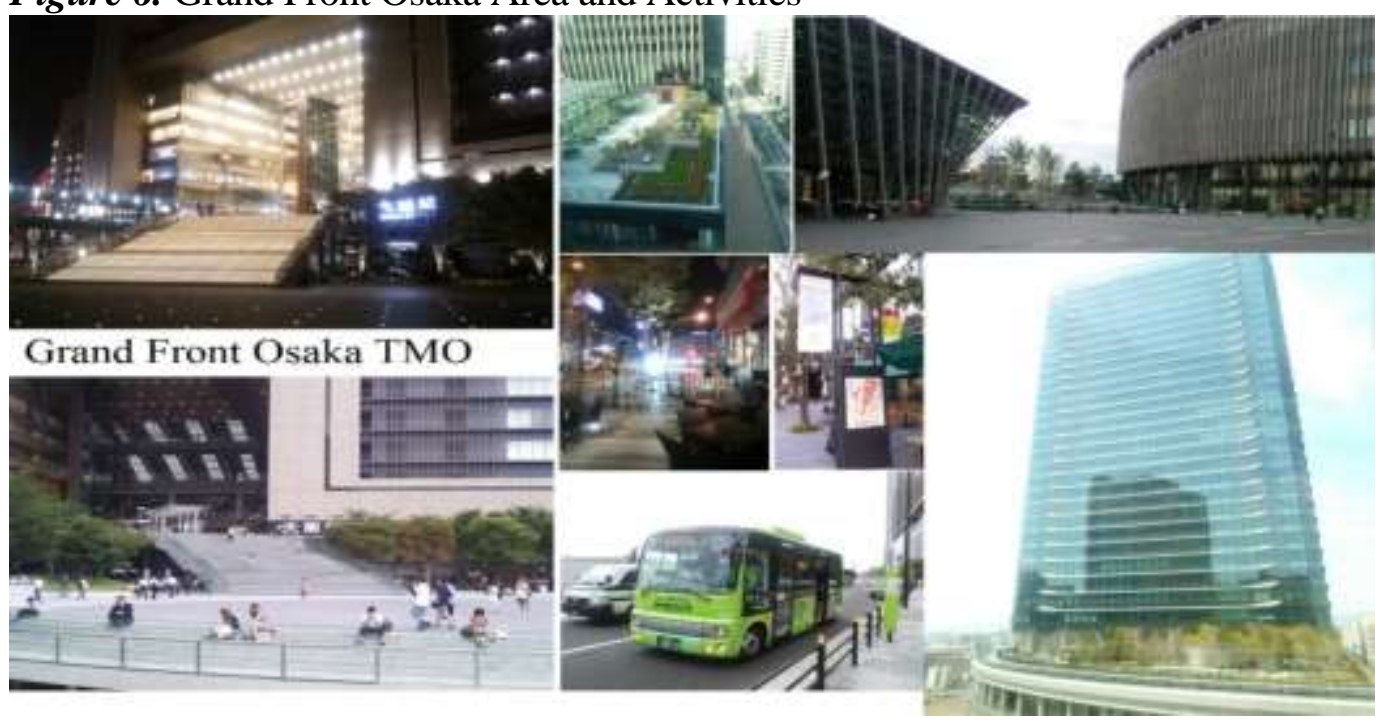

Grand Front Osaka is a newly developed area containing commercial buildings, hotels, residential accommodation, a gallery, learning centre, etc. It is located in the northern area of Osaka Station; the traffic hub of the third largest city in Japan. Grand Front Osaka TMO is a general incorporated association with 12 members of Grand Front Osaka landowners. The Osaka City Government has designated Grand Front Osaka TMO as an"Urban Regeneration Development Corporation". The concept of Grand Front Osaka TMO is to improve the value of the whole Umeda District (area around Osaka Station).Its concrete objectives are revitalisation, environmental improvement, and community development of Grand Front Osaka and the surrounding area. The main activities involve the management and operation of a pedestrianised, public plaza (Umekita Square) and other open spaces, community bus service, and bicycle rental.Grand Front Osaka TMO also offers operating guidelines for business advertising, landscape control, creating and promoting a network for visitors, office workers, events, and promotions. The characteristics and role of Grand Front Osaka TMO can be explained as follows: Grand Front Osaka TMO is the first and only case of a Business Improvement District (BID) ${ }^{1}$ in Japan; secondly, using the pavement of a public road for open air cafés, outdoor advertisements, and as a roadway for certain events by national deregulation; thirdly, ordinance deregulation in return for landscape guidelines to control outdoor advertisements, using the revenue generated towards Machizukuri ${ }^{2}$ activities.

\footnotetext{
${ }^{1} \mathrm{BID}=$ partnerships between local authorities and businesses intended to provide additional services or improvements to a specified area. BIDs are funded in whole or part by special assessments, levies, or additional taxes onbusiness operators in the UK and property owners in the US. (Mitarai and Suebsuk 2016).

${ }^{2}$ Machizukuri is a revitalisation and townscape planning project for the city.
} 


\section{$\underline{\text { Sapporo-Odori Machizukuri Company Limited }}$}

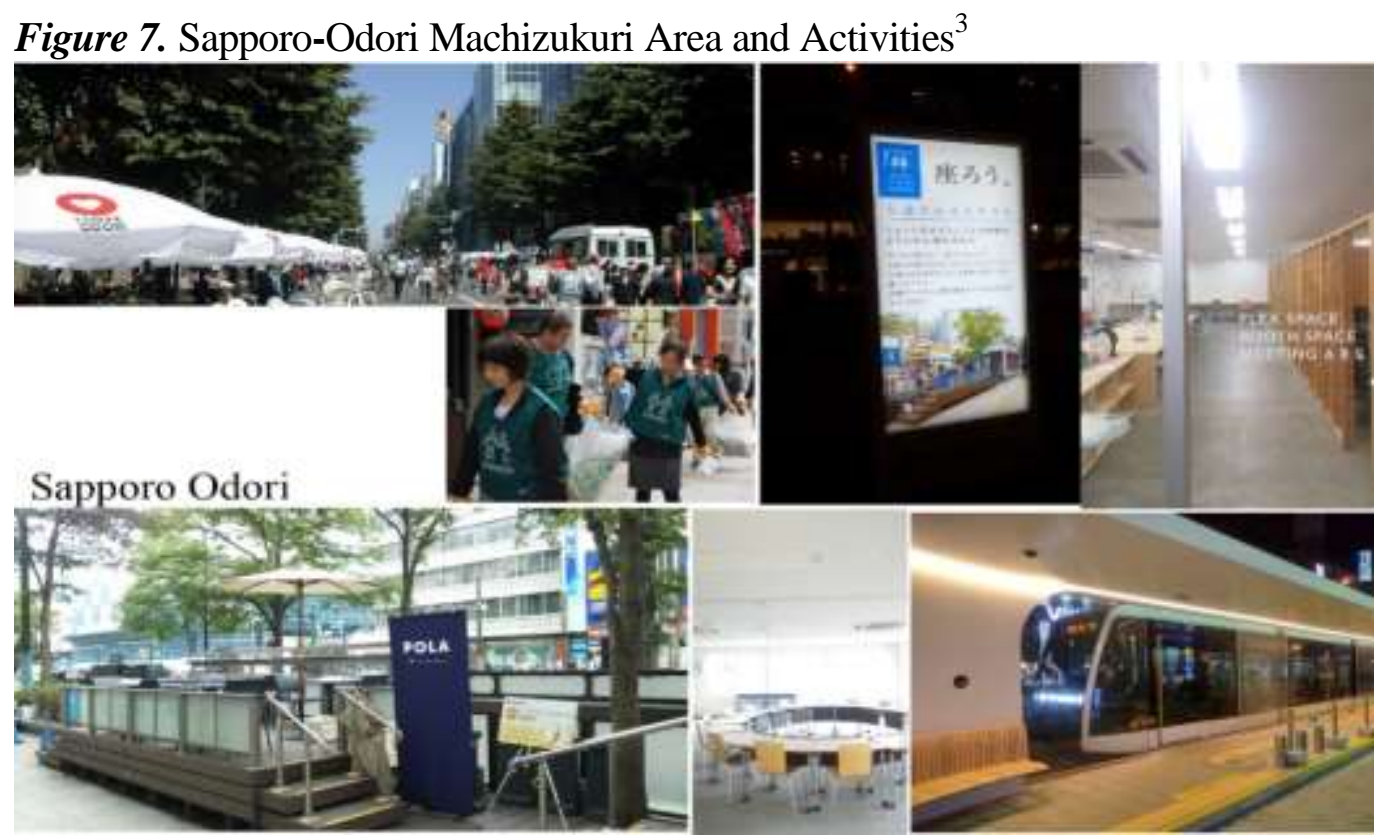

Sapporo is the largest city in the Hokkaido prefecture, northern Japan. Odori is the old commercial area. Ten years ago the centre of the city moved, producing a substantial effect on the shop owners of Odori. Sapporo-Odori Machizukuri was established on 1 September 2009 with the objective of managing the Odori project. The characteristics and role of the company areto revitalise the Odori streets into a central shopping area. The organisation continuously carries out Machitsukuri activities; a famous example of which isthe useof public spaces (such as roads) to enhance the community network, increase the visitor numbers and obtain extra revenue. This type of revenue is different from that of a private companyin that all profits obtained from the project are reinvested to enhance the value of the area and improve and expand public interest. 


\section{$\underline{\text { Koto ni Moeru Kai (Ichinenzaka Ninenzaka District,Kyoto) }}$}

Figure 8. Koto ni Moeru Kai Area

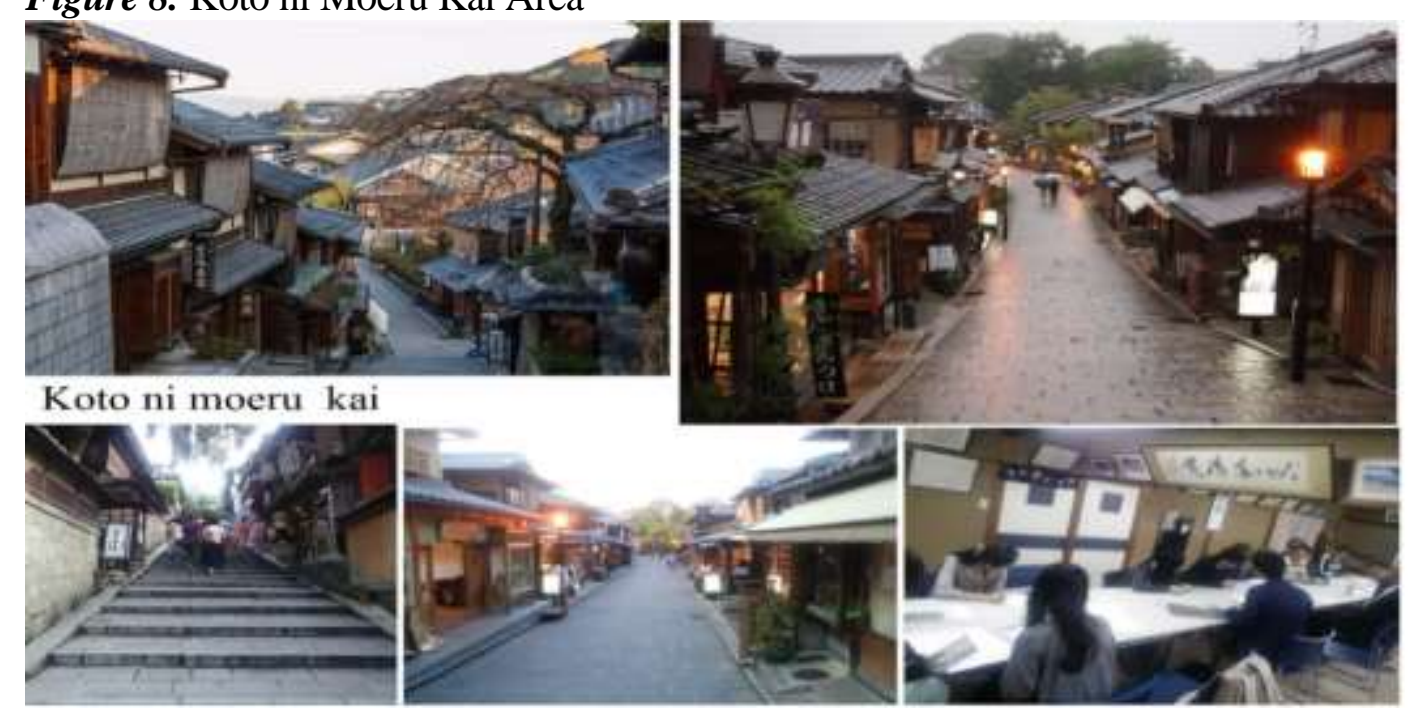

Kyoto is the former capital of Japan, and an area famous for traditional old style wooden shop houses (Machiya) along roads connected to major tourist spots and historic sites. One of its special characteristics is the original townscape development plan. The regulation control created by a community called Koto ni Moeru Group (a community group protecting the old city landscape known as the Ichinenzaka Ninenzaka Area Management Organisation, established in 1986). The community plan has been certified by Kyoto city, based on its ordinance to regulate and control the townscape such as with colour, size, material, fabric, roof and style of architecture, outdoor advertising schemes, etc.,to retain as much as possibleof the historical environment. The purpose of the group is to revitalise not only Kyoto sightseeing spots but also provide a commercial area and living space for people in the neighbourhood.

\section{Previous Studies}

Town Centre Management (TCM) in the UK operates a similar system to ABM in Japan and has been working effectively since 1990. Thus far, more than 300 town managers have been appointed by TCM to local towns - their main task being to make the town centre economically vibrant (Ueno et al. 2017). In addition, the Business Improvement District (BID) system, which can be explained as a legal fund-raising system for TCM or ABM was introduced in the UK during 2004. Throughout the UK and Ireland there were 279 BIDs in 2016 (British BIDs 2016). To be more accurate, BIDs are defined as non-profit public/private partnerships in which property and business owners come together to make a collective financial contribution to the maintenance development and promotion of their commercial district (SBS NYC 2015), and the biggest difference between 
$\mathrm{BID}$ and the normal fund-raising system of $\mathrm{ABM}$ is that it affords local governments with the legal power to impose an additional tax or assessment on the land occupier or owner in designated areas (BID areas). The BID system has also been instituted in other countries such as the US and Germany. Thus, in the UK, US, and Germany, the ABM or town management system has been activated with the use of legal frameworks, whereas in Japan, it remains in the initial phase since no BID system has been instituted.

There is only a limited amount of international research or articles on ABM in Japan, interpreted in various ways. Kinoshita and Yasui mentioned the concept of "district management" in their paper (Kinoshita and Yasui 2012) on development in Japan and identify its characteristics and issues following changes in the economic policy for city centres since the 1940s. District management projects focus on voluntary business participation - rather than government, with companies independently working on the project, and local landowners and business owners playing an important role by collaborating or networking using local spaces, buildings, and infrastructure.The challenge is to secure equal and suitable funding for the revitalisation of central urban areas in Japan in the future.

Sorensen, Koizumi, and Miyamoto mention "community and development", "neighbourhood building", or "town making" in the context of "Machizukuri" which is used to describe an extraordinarily wide variety of activities from economic development initiatives to traditional top-down city planning, urban renewal projects, and voluntary social welfare projects (Sorensen et al. 2009 ). The article concludes with a few core characteristics on most Machizukuri processes. Most organisations remain entirely voluntary with small, autonomous, neighbourhood-based groups without any paid staff. They tend to work at the neighbourhood scale, from several hundred to a few thousand residents. Their main authority lies not in the legal planning system but by persuasion, relying on community ordinance. A core function of the Machizukuri process is in the production of shared rule and norms relating to shared spaces by understanding the limits of the public rights of others. One of the great achievements of the Machizukuri movement is the creation of new forms of civic engagement and membership patterns, types and uses for civic spaces, and different associated behaviour for enhancing life space and protecting the qualities of the place for current and future generations.

An ABM survey in Japan for 2015 and 2016 was used by Ueno, Adachi and Mitarai (Ueno et al. 2017). The paper focused on the impact of ABM by conducting several empirical tests on revitalisation of the town and the hypothesis was verified by a logistical model and found no correlation between government subsidies and management assessment. A positive correlationwas found between assessment and funding from membership fees, etc, and no correlation existed between the history of the organisation and the assessment of it.

Mitarai and Suebsuk (Mitarai and Suebsuk 2016) made a comparative analysis of performance indicators and information disclosure on ABM samples in Tokyo and analysed indicators from annual report reviews of similar cases in Japan, the US, and the UK.

As mentioned above, there are few studies on ABM in Japan in the English 
language. But the expression "Area Management" (ABM in Japanese) began to appear in Japanese papers and articles in approximately 2002, increasing after 2007 (Hirao and Mitarai 2017). Overviewing the previous studies in Japanese on ABM, Lee and Kobayashi (Lee and Kobayashi 2004) studied the Daimaruyu area where the first and one of the most famous ABM organizations in Japan is located in the commercial area of a large city centre. Some case or comparative studies have also tried to clarify the activities and organisations of ABM in large city commercial areas (Lee and Kobayashi 2005, Asai et al. 2002, Fukuokaet al. 2008, Cho and Deguchi 2009). Other literature such as Saitou (Saitou 2003, 2010) and Watanabe and Arita (Watanabe and Arita 2016) focus on area management in residential areas. Based on these basic research studies, some papers appear to focus on public space management (Izumiyama 2015) by attempting to make the business model visible, while Tenmyo and Kobayashi (Tenmyo and Kobayashi 2006) and Izumiyama, Akiyama and Kobayashi (Izumiyama et al. 2015) focus in particular on public space management under the ordinance of the Tokyo Metropolitan Government. Izumiyama and Kobayashi (Izumiyama and Kobayashi 2013) focus on public space management under the special provisions of the national act such as Act on Special Measures concerning Urban Reconstruction, mentioning public space as a potential financial source. Saito et al. (Saito et al. 2009) also fous on financial source of ABM from public space management.

Therefore, this paper concerns the overall image of ABM with the use of a nationwide survey of Japan, prioritising to clarify the whole ABM situation in Japan for its international transmission.

\section{Methodology}

To investigate the actual comprehensive situation of ABM in Japan, an extensive nationwide survey via questionnaire was conducted for two periods by Kyoto University in cooperation with the Ministry of Land, Infrastructure, Transportation and Tourism, City Bureau Urban Renewal Promotion Division, and the Faculty of Economics, Wakayama University.

The first period of the ABM survey starts from November 2014 to January 2015 and was sent by e-mail and attached file to 826 municipalities of the Urban Regeneration Improvement Plan completed at the end of the 2012 financial year (total 1,524 plans). Since the Urban Regeneration Improvement Plan is positioned as a platform for public-private partnership and Machizukuri by the national government of Japan (Ministry of Land, Infrastructure, Transportation and Tourism). The 42 survey questionnaires were divided into four parts: basic information; the Urban Regeneration Improvement Plan; situation, implementation and effects of $\mathrm{ABM}$ within the plan area; and land prices in or near the plan area. Officials from 746 municipalities responded (90.3\%). The number of responding districts, including those with no ABM organisations was 1,322 (86.7\%). Data from 574 ABM organisations was collected, with no more than three organizations within one plan area, due to the possibility that plural ABM organisations may 
exist in a certain area.

In the second period, the ABM survey via questionnaire was conducted from August to September 2015 in 314 municipalities in response to the first survey that ABM organisations exist. The answers are from municipal officials, as in the first survey, with 269 municipalities responding (86\%). The survey involved a maximum of 52 questionnaires on the purpose of ABM organisations, the reasons for $\mathrm{ABM}$ organisation establishment, original support for $\mathrm{ABM}$ by municipalities, and so on. Data from 464 ABM organisations was collected.

\section{Findings and Discussion}

In this chapter, data from the ABM survey is discussed to understand the actual situation of ABM organisations in Japan with the six data topics consist of the objectives of $A B M$, establishment and motivation of $A B M$ organisations, ABM activities, characteristics of ABM organisations, and effects and problems of $A B M$ organisations. Cross analysis is then carried out with the aim of advising on the functional improvement of ABM latter part of this chapter

\section{Objectives of $A B M$}

\section{Objectives of ABM Organisations}

Table 1. What are the Objectives of ABM? (Multiple Answers)

\begin{tabular}{|ll|c|c|}
\hline Objective & Answers & $\begin{array}{c}\text { Ratio from } \\
\text { answered orgs. }\end{array}$ \\
\hline $1 . \quad$ To create a suitable or beautiful landscape & 283 & $61 \%$ \\
\hline 2. & $\begin{array}{l}\text { To enhance visitor numbers (customers, passengers, } \\
\text { travellers, tourists, etc.) }\end{array}$ & $68 \%$ \\
\hline $3 . \quad \begin{array}{l}\text { To improve the real estate effect (to reduce empty buildings, } \\
\text { shops, or vacancy rates, to increase rent, etc.) }\end{array}$ & 105 & $23 \%$ \\
\hline $4 . \quad \begin{array}{l}\text { Economic vitalisation (to increase consumption, merchandise, } \\
\text { or employment) }\end{array}$ & 181 & $39 \%$ \\
\hline 5. & Disaster prevention, crime prevention, or public safety & 180 & $39 \%$ \\
\hline 6. & $\begin{array}{l}\text { To enhance community power, mutual understanding, or } \\
\text { networking }\end{array}$ & 311 & $67 \%$ \\
\hline $7 . \quad \begin{array}{l}\text { To reducethe financial burden such as lower costs for } \\
\text { maintenance of public facilities }\end{array}$ & 87 & $19 \%$ \\
\hline $8 . \quad \begin{array}{l}\text { To create public awareness of the area or increase recognition } \\
\text { for ABM activities }\end{array}$ & 194 & $42 \%$ \\
\hline 9. & $\begin{array}{l}\text { To cope with regional competition (to increase workersor } \\
\text { population, or crisis management) }\end{array}$ & 90 & $19 \%$ \\
\hline 10. & Other & 54 & $12 \%$ \\
\hline
\end{tabular}


Table 2. Main Objective of an ABM org. (only one answer)

\begin{tabular}{|c|c|c|c|}
\hline \multicolumn{2}{|c|}{ Contents } & \multirow{2}{*}{\begin{tabular}{|l|} 
Answers \\
136
\end{tabular}} & \multirow{2}{*}{$\begin{array}{l}\text { Ratio from answered orgs. } \\
29 \%\end{array}$} \\
\hline 1. & To create a suitable or beautiful landscape & & \\
\hline 2. & To enhance the visitor numbers (customers, passengers, travellers, tourists, etc.) & 159 & $34 \%$ \\
\hline 3. & To improve the real estate effect (to reduce empty buildings, shops, or vacancy rates to increase rent, etc.) & 4 & $1 \%$ \\
\hline 4. & Economic vitalisation (to increase consumption, merchandise, or employment) & 8 & $2 \%$ \\
\hline 5. & Disaster prevention, crime prevention, or public safety & 12 & $3 \%$ \\
\hline 6. & To enhance community power, mutual understanding, or networking & 64 & $14 \%$ \\
\hline 7. & To reducethe financial burden such as lower costs for the maintenance of public facilities & 10 & $2 \%$ \\
\hline 8. & To create public awareness of the area or increase recognition for ABM activities & 10 & $2 \%$ \\
\hline 9. & To cope with regional competition (increase workers or the population, or crisis management) & 1 & $0 \%$ \\
\hline & C & 33 & $7 \%$ \\
\hline No & wer provided & 27 & $6 \%$ \\
\hline Tot & & 464 & $100 \%$ \\
\hline
\end{tabular}


The question on the objectives of ABM organisations involved multiple answers, the aggregate resultsof which are shown in Table 1 refers to the ratio of each answer from the total number collected from the survey (574). The same ratio also applies to the other tables.

From the data in Table 1, the greatest number of ABM objectivesare: 2. to enhance visitor numbers (customers, passengers, travellers, tourists, etc.) at 68\%; 6. to enhance community power, mutual understanding, or networking at $67 \%$; and 1 . to create a suitable or beautiful landscape at $61 \%$.

\section{Main Objective of an ABM Organisation}

This question focuses on the main objective of an $\mathrm{ABM}$ organisation for which only one answer is collected (as shown in Table 2).

In Table 2, the greatest number of main objectives for ABM are: 2. to enhance visitor numbers (customers, passengers, travellers, tourists, etc.), and 1. to create an appropriate or beautiful landscape, followed by 6. to enhance community power, mutual understanding, or networking. The other reasons are few. When reconsidering the data in Table 1, it could be implied that ABM in Japan has three main objectives (2. to enhance the visitor numbers, 1 . to create an appropriate or beautiful landscape, and 6 . to enhance community power, mutual understanding, or networking), with 6 . being collateral when compared to theother two.

\section{Establishment and Motivation. Why Start an ABM?}

\section{$\underline{\text { Organisational Motivation for Starting ABM Activities }}$}

Table 3. What Motivates Organisations to Start ABM Activities? (Multiple Answers)

\begin{tabular}{|l|c|c|}
\hline Motivation & Answers & $\begin{array}{c}\text { Ratio from } \\
\text { answered orgs. }\end{array}$ \\
\hline $\begin{array}{l}\text { 1. Quality of life; recognising and raising the satisfaction } \\
\text { of people in the community such as with landscape or } \\
\text { security improvements }\end{array}$ & 213 & $46 \%$ \\
\hline $\begin{array}{l}\text { 2. Economy; concerned about the economic revitalisation of } \\
\text { the region due to the declining shopping district or } \\
\text { population }\end{array}$ & 152 & $33 \%$ \\
\hline $\begin{array}{l}\text { 3. Competition; since there is high competition between } \\
\text { cities or areas, the area needs to be strong }\end{array}$ & 98 & $21 \%$ \\
\hline $\begin{array}{l}\text { 4. Motivation; other ABM examples are inspirational and } \\
\text { can be applied to the area }\end{array}$ & 109 & $23 \%$ \\
\hline $\begin{array}{l}\text { 5. Networking; strengthening networks and connections } \\
\text { between stakeholders such as residents, businesses, and } \\
\text { the public sector }\end{array}$ & 234 & $50 \%$ \\
\hline $\begin{array}{l}\text { 6. Continuation; proceeding with activities from original } \\
\text { organisationsinthe area (there is a long history of } \\
\text { community groups, merchant chambers, etc.) }\end{array}$ & 136 & $29 \%$ \\
\hline 7. Financial; reduce the burden of maintenance costs & 42 & $9 \%$ \\
\hline 8. Other & 63 & $14 \%$ \\
\hline
\end{tabular}


Table 3 shows the results of organizational motivation to start ABM activities. The three highest results are: 5. networking; strengthening networks and connections between stakeholders such as residents, business, and the public sector $(50 \%)$; 1 . quality of life; recognising and raising the satisfaction of people in the community such as with landscape or security improvements (46\%); and 2. economy; concerned about the economic revitalisation of the region due to the declining shopping district or population (33\%). It can therefore be implied that organisational motivation for starting $\mathrm{ABM}$ activities is particularly concerned with the strength of the community, quality of life (QOL), and economic factors.

\section{$\underline{\text { ABM Organisational Initiatives }}$}

Figure 9. ABM Organisational Initiatives

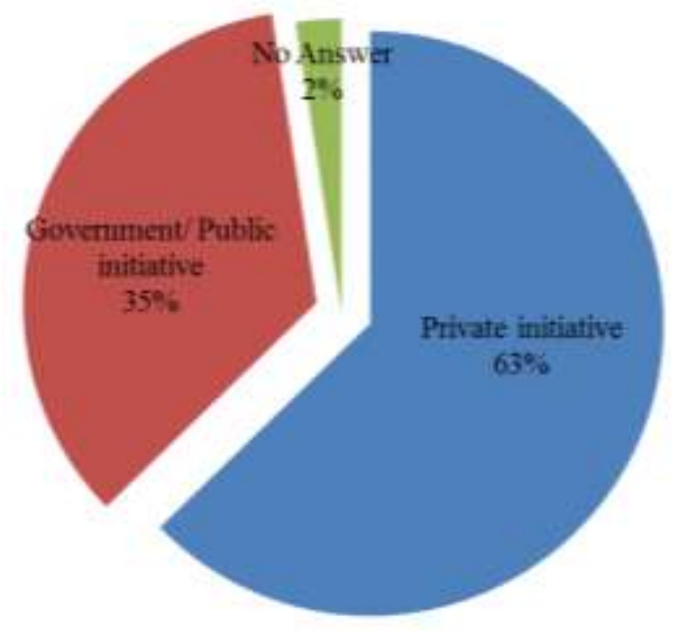

Figure 9 shows the percentage of ABM activities initiated byt he public or private sector. The results show that $63 \%$ are private initiatives. However, although area management is defined as "a private initiative by the people", $35 \%$ remain government initiatives. The cause of this could be considered as the requirement of this questionnaire that it be answered by officials of the municipality.

It may be meaningless to ascertain the exact establishment period of an ABM organisation when researching its history. This is because some organisations have been established a long time ago although some ABM activities started after long time of the organisation establishment, or some organisations may have been developed from a small-scale with the organisation changing its corporate formation later. Therefore, to check the establishment time of an ABM organisation in this research, the time is assessed according to when member/ activities and attendance evolved into the present situation (Figure 10). 
Establishment Period for an ABM Organisation

Figure 10. Approximate Year When the Organisation Evolved into its Present Situation: Members/Activities and Attendance

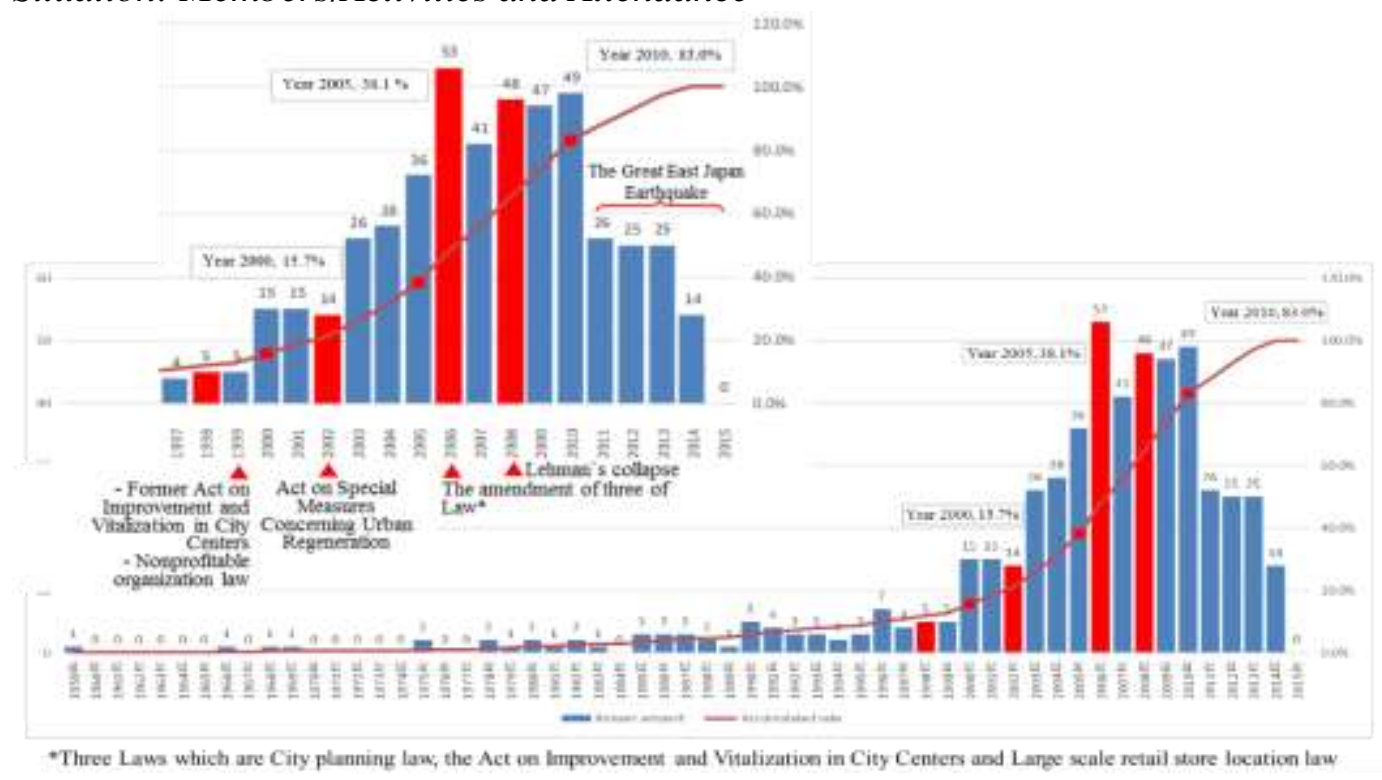

The results indicate that approximately in 2000 the number of $\mathrm{ABM}$ organisations gradually increased.Such increase occurred mightdue to the following legislation: "The (Former) Act on Improvement and Vitalization in City Centers","Act on Special Measures Concerning Urban Regeneration", "The amendment of the Three Laws ${ }^{l}$ concerning Machizukuri", or the formulated plan or ordinance of private community organisationsby local government influenced by these Acts (Figure 10).

After 2011, the number decreased, possibly as a resultof the recovery activity and reconstruction work required following the great East Japan earthquake.

\section{Activities}

\section{The Main ABM Activity in the Beginning}

Regarding the activities during the beginning phase of an ABM organisation, in this study, its activities are categorised into six types (A-F)as shown in Table 4. The results indicate that the highest number of activities chosen in the beginning phase of an ABM is in category B "Event and activity". Because this number is less than half of the respondent organisations (49.7\%), it could be implied that it is difficult to mention the typical ABM activities, and ABM organisation manages a wide range of activities in various categories.

As discovered from the results of each category, the smallest number chosen for anactivity during the beginning phase of $\mathrm{ABM}$ comes under category $\mathrm{F}$

\footnotetext{
${ }^{1}$ Three Laws: City Planning Law, The Act on Improvement and Vitalization in City Centers, and Large-Scale Retail Store Location Law.
} 
"Improvement of regional attractiveness, value, or convenience offered by the public use of private facilities".

Table 4. Main Activities during the Beginning Phase (Multiple Answers)

\begin{tabular}{|l|c|c|c|}
\hline Activity type & Answers & $\begin{array}{c}\text { Composition } \\
\text { ratio }\end{array}$ & $\begin{array}{c}\text { Ratio from } \\
\text { answered } \\
\text { orgs. }\end{array}$ \\
\hline A. Machizukuri rules, etc. & 224 & $20.0 \%$ & $39.0 \%$ \\
\hline B. Event, activity & 285 & $25.4 \%$ & $49.7 \%$ \\
\hline C. Information transmission & 188 & $16.8 \%$ & $32.8 \%$ \\
\hline $\begin{array}{l}\text { D. } \text { Disaster prevention, crime } \\
\text { prevention, providing a sustainable } \\
\text { environment }\end{array}$ & 211 & $18.8 \%$ & $36.8 \%$ \\
\hline $\begin{array}{l}\text { E. Maintenance and management of } \\
\text { public facilities or spaces }\end{array}$ & 144 & $12.8 \%$ & $25.1 \%$ \\
\hline $\begin{array}{l}\text { F. Improvement of regional } \\
\text { attractiveness, value or convenience } \\
\text { offered by the public use of private } \\
\text { facilities }\end{array}$ & 69 & $6.2 \%$ & $12.0 \%$ \\
\hline Total & 1121 & $100.0 \%$ & - \\
\hline
\end{tabular}

Number of Activity Types per Organisation

Table 5. Activity Type and Number of Organisations during the Beginning Phase

\begin{tabular}{|l|c|}
\hline Activity Type & Organisations \\
\hline 0 & 10 \\
\hline 1 & 274 \\
\hline 2 & 127 \\
\hline 3 & 93 \\
\hline 4 & 43 \\
\hline 5 & 20 \\
\hline 6 & 7 \\
\hline Total & 574 \\
\hline
\end{tabular}

The research also provides the number of activity types per organisation during the beginning phase. The results show that more than half of organisations operate only one type of activity in the beginning phase of ABM (274). The other half operates more than one type of activity (Table 5). 
Number of Activity Types Categorised By City Scale and Land Usage

Table 6. The Average Number of Activity Types by City Scale and Land Usage

\begin{tabular}{|c|c|c|c|c|c|}
\hline $\begin{array}{l}\text { City } \\
\text { Population }\end{array}$ & $\begin{array}{c}\text { Less } \\
\text { than } \\
50,000\end{array}$ & $\begin{array}{l}50,000 \text {-less } \\
\text { than } 200,000\end{array}$ & $\begin{array}{c}200,000-\text { less } \\
\text { than } \\
500,000\end{array}$ & $\begin{array}{c}500,000 \\
\text { and over }\end{array}$ & Average \\
\hline Land Usage & & & & & \\
\hline Commercial & 1.49 & 1.95 & 2.20 & 2.08 & 1.91 \\
\hline Residential & 1.54 & 1.81 & 1.79 & 1.33 & 1.69 \\
\hline Average & 1.51 & 1.90 & 2.05 & 1.94 & 1.83 \\
\hline
\end{tabular}

The survey shows the average number of activity types during the beginning phase of an ABM organisation by city scale and land usage (Table 6). The results indicate a total average of 1.83 activity types.ABM organisations in commercial areas have more types of activity (1.91) on average than those in residential areas (1.69).

Residential areas have more activity types than commercial only in smallscalecities with populations of less than 50,000. Whereas the activity types in commercial areas tend to be higher than residential in big scale cities, with populations of more than 50,000.

\section{Cross Analysis by the Main Activities of ABM}

From the answers concerning the main activity in the beginning period of ABM in Tables 4 and 6, many ABM organisations do various types of activities. Table 7 is created by cross analysis of ABM main activity type in the beginning stage to find which activity type is combined together with other activity types.

The results in Table 7 indicate that the combination of ABM activities can be explained as follows: A (Machizukuri's rule) has a small percentage when combined with other activities, but its independent value is quite high (41.5\%). Comparing the other activities, independent valuesare quite low, especially for $\mathbf{C}$ (information transmission) and $\mathbf{F}$ (improvement of regional attractiveness, value, or convenience by the public use of private facilities) which is less than $10 \%$, indicating that more than $90 \%$ of these activity types operate in conjunction with others. However, the characteristics of $\mathbf{C}$ and $\mathbf{F}$ might not be similar to each other. Type $\mathbf{C}$ are likely to be easy activities but not sufficiently effective. Therefore, to become more effective, type $\mathbf{C}$ activities should operate together with the other types (high percentage rather than independent). On the other hand, type $\mathbf{F}$ activities are quite difficult since the figure is quite low (69). Based on further analysis from the same data, it is predicted that only a high-level organisation can operate the activities in this category. Usually high level organisations manage a range of activities which is why type $\mathbf{F}$ is automatically combined with others. 
Table 7. Combination of ABM Activities (A-F Activities are taken from Table 4)

\begin{tabular}{|c|c|c|c|c|c|c|c|c|}
\hline & A.Rule & B.Events & C.Info & D.Safety & $\begin{array}{c}\text { E.Maintenace } \\
\text { of public } \\
\text { spaces }\end{array}$ & $\begin{array}{l}\text { F.Public } \\
\text { use of } \\
\text { private } \\
\text { facilities }\end{array}$ & $\begin{array}{l}\text { Independent } \\
\text { amounts }\end{array}$ & \begin{tabular}{|c|} 
Activities \\
from \\
answer \\
amount in \\
Table 4 \\
\end{tabular} \\
\hline \multirow{2}{*}{ A. Rule } & & 80 & 76 & 82 & 44 & 26 & 93 & \multirow{2}{*}{224} \\
\hline & & $35.7 \%$ & $33.9 \%$ & $36.6 \%$ & $19.6 \%$ & $11.6 \%$ & $41.5 \%$ & \\
\hline \multirow{2}{*}{ B. Event } & 80 & & 138 & 107 & 73 & 45 & 79 & \multirow{2}{*}{285} \\
\hline & $28.1 \%$ & & $48.4 \%$ & $37.5 \%$ & $25.6 \%$ & $15.8 \%$ & $27.7 \%$ & \\
\hline \multirow{2}{*}{ C. Info } & 76 & 138 & & 76 & 64 & 45 & 11 & \multirow{2}{*}{188} \\
\hline & $40.4 \%$ & $73.4 \%$ & & $40.4 \%$ & $34.0 \%$ & $23.9 \%$ & $5.9 \%$ & \\
\hline \multirow{2}{*}{ D. Safety } & 82 & 107 & 76 & & 54 & 27 & 60 & \multirow{2}{*}{211} \\
\hline & $38.9 \%$ & $50.7 \%$ & $36.0 \%$ & & $25.6 \%$ & $12.8 \%$ & $28.4 \%$ & \\
\hline \multirow{2}{*}{$\begin{array}{l}\text { E.Maintenance } \\
\text { of public spaces }\end{array}$} & 44 & 73 & 64 & 54 & & 32 & 26 & \multirow{2}{*}{144} \\
\hline & $30.6 \%$ & $50.7 \%$ & $44.4 \%$ & $37.5 \%$ & & $22.2 \%$ & $18.1 \%$ & \\
\hline \multirow{2}{*}{$\begin{array}{l}\text { F. Public use of } \\
\text { private facilities }\end{array}$} & 26 & 45 & 45 & 27 & 32 & & 5 & \multirow{2}{*}{69} \\
\hline & $37.7 \%$ & $65.2 \%$ & $65.2 \%$ & $39.1 \%$ & $46.4 \%$ & & $7.2 \%$ & \\
\hline
\end{tabular}

Activity types $\mathbf{B}$ and $\mathbf{C}$ have a strong likelihood of being combined with other activities, except type $\mathbf{A}$. It could be implied that $\mathbf{B}$ and $\mathbf{C}$ have a strong affinity to other activities.

\section{Main ABM Activities at the Present Time}

Table 8. Main Activities at the Present Time (by Three Answers)

\begin{tabular}{|l|c|c|c|}
\hline Activity Type & Answers & $\begin{array}{c}\text { Composition } \\
\text { ratio }\end{array}$ & $\begin{array}{c}\text { Ratio from } \\
\text { answered } \\
\text { orgs. }\end{array}$ \\
\hline A. Machizukuri's rule, etc. & 175 & $16.5 \%$ & $30.5 \%$ \\
\hline B. Event, activity & 316 & $29.9 \%$ & $55.1 \%$ \\
\hline C. Information transmission & 154 & $14.6 \%$ & $26.8 \%$ \\
\hline $\begin{array}{l}\text { D. Disaster prevention, crime } \\
\text { prevention, providing a sustainable } \\
\text { environment }\end{array}$ & 208 & $19.7 \%$ & $36.2 \%$ \\
\hline $\begin{array}{l}\text { E. Maintenance and management of } \\
\text { public facilities or spaces }\end{array}$ & 144 & $13.6 \%$ & $25.1 \%$ \\
\hline $\begin{array}{l}\text { F. Improvement of regional } \\
\text { attractiveness, value or convenience by } \\
\text { the public use of private facilities }\end{array}$ & 61 & $5.8 \%$ & $10.6 \%$ \\
\hline Total & 1058 & $100.0 \%$ & - \\
\hline
\end{tabular}

Regarding the main activities of an ABM organisation at the present time, questionnaires with 31 detailed categories were chosen to provide three answers. 
Table 8 represents the aggregated data for the main activities of 31 detailed categories into six types. The total number of activities is 1,121 (Table 4) with 576 organisations, and it can therefore be calculated that there are approximately 1.95 activities per group. This shows that an ABM organisation operates about 2 (1.95) activities on average.

Comparing the answers in Table 8 with the multiple answers in Table 4, the total numberof activities reduces from 1,121 to 1,058 , respectively according to the different methods used (multiple during the beginning phase and no more than three answers for the present). Regarding the change with Table 4, A (Machizukuri's rule) has decreased most (-8.5\%), whereas B (event and activity) has increased most $(+5.4 \%)$.

From this aspect, it could be implied that A (Machizukuri's rule) is not primarily considered a top activity, or considered a top activity at the time of rule establishment (beginning) but this situation could subsequently change. However, it could be implied that $\mathbf{B}$ (event and activity)is considered a top activity, or may be difficult to operate in the beginning phase but becomes easier as the organisation develops.

\section{Change in ABM Activities from the Beginning Phase to the Present Time}

As set out in paragraph 4.3.5, the number of type A activities (Machidukuri's rule.) decreased and $\mathbf{B}$ (event and activity) increased from the beginning phase. This topic focused on the analysis of changing activities from the beginning phase to the present time.The ABM surveys for the two periods contained different points. Questionnaires on the beginning phase provided multiple answers for six activity types Questionnaires regarding the present time, containing 31 details were scrutinised, with the answers limited to no more than three. For comparison, cross analysis by the number of activities during the beginning phase and present time is shown in Table 9, rearranged in horizontal ranking in Table 10 to find a relationship between $\mathbf{A}-\mathbf{F}$.

Table 9. Relationship between the Main Activity during the Beginning Phase and Present Time (by Number of Organisations)

\begin{tabular}{|l|l|l|l|l|l|l|l|}
\hline \multicolumn{1}{|c|}{ Present } & $\begin{array}{c}\text { A. } \\
\text { Rule }\end{array}$ & $\begin{array}{c}\text { B. } \\
\text { Event }\end{array}$ & $\begin{array}{c}\text { C. } \\
\text { Info }\end{array}$ & $\begin{array}{c}\text { D. } \\
\text { Safety }\end{array}$ & $\begin{array}{c}\text { E. } \\
\text { Maintenance } \\
\text { of public } \\
\text { spaces }\end{array}$ & $\begin{array}{c}\text { F. } \\
\text { Public } \\
\text { use of } \\
\text { private } \\
\text { facilities }\end{array}$ & Total \\
\hline A. Rule & 167 & 78 & 48 & 73 & 44 & 10 & 420 \\
\hline B. Event & 50 & 293 & 97 & 87 & 68 & 39 & 634 \\
\hline C. Info & 45 & 131 & 107 & 56 & 60 & 34 & 433 \\
\hline D. Safety & 45 & 101 & 40 & 183 & 55 & 14 & 438 \\
\hline E.Maintenance of public spaces & 21 & 65 & 35 & 43 & 128 & 23 & 315 \\
\hline F.Public use of private facilities & 7 & 39 & 20 & 14 & 26 & 51 & 157 \\
\hline
\end{tabular}


Table 10. Relationship between the Main Activity during the Beginning Phase and Present Time by Horizontal Ranking (Taken from Table 9)

\begin{tabular}{|l|c|c|c|c|c|c|}
\hline & A.Rule & B.Event & $\begin{array}{c}\text { C.Inf } \\
\text { o }\end{array}$ & D.Safety & $\begin{array}{c}\text { F. } \\
\text { E.Maintenan } \\
\text { ce of Public } \\
\text { Spaces }\end{array}$ & $\begin{array}{c}\text { Public } \\
\text { Use of } \\
\text { Private } \\
\text { Facilitie } \\
\text { s }\end{array}$ \\
\hline A.Rule & 1 & 2 & 4 & 3 & 5 & 6 \\
\hline B.Events & 5 & 1 & 2 & 3 & 4 & 6 \\
\hline C.Info & 5 & 1 & 2 & 4 & 3 & 6 \\
\hline D. Safety & 4 & 2 & 5 & 1 & 3 & 6 \\
\hline $\begin{array}{l}\text { E. Maintenance of } \\
\text { public spaces }\end{array}$ & 6 & 2 & 4 & 3 & 1 & 5 \\
\hline $\begin{array}{l}\text { F. Public use of } \\
\text { private facilities }\end{array}$ & 6 & 2 & 4 & 5 & 3 & 1 \\
\hline Average & 4.5 & 1.7 & 3.5 & 3.2 & 3.2 & 5.0 \\
\hline
\end{tabular}

Horizontal ranking: $1=$ Highest number of organisations (dark pink) $2=$ second highest number of organisations (light pink) to $6=$ lowest number of organisations (no colour)

The data explains the relationship between the main activities during the beginning phase and present time by ranking the highest number of organisations in six groups (Table 10). Therefore, the activities carried out during the beginning phase are likely to be repeated or continued. In addition, the data could explain what types of activity are operated during the beginning period, after which B (events and activities) are more likely to occur (continuously or additionally). However, it is indicated that A (Machizukuri's rule), if not started during the beginning phase, is unlikely to start after ABM has already been set in place.

\section{Main Activities of ABM at the Present Time (Details)}

The ABM activities for the present time have been categorised into 31 details of six types. In Table 8, it can be seen that $\mathbf{B}$ (event and activity) has the highest number in similarity to the beginning phase (Table 4), but the category details vary. In this section, "Greenery beautification and cleanliness" is ranked highest out of 31 detailed activities, but only $23 \%$ of organisations operate it (Figure 14). It could also be implied that ABM activities have a wide range of variations in detail as mentioned in "The main ABM activity in the beginning". 


\section{$\underline{\text { A. Machizukuri's Rules }}$}

Figure 11. Main Activities at the Present Time (by Machizukuri's Rules)

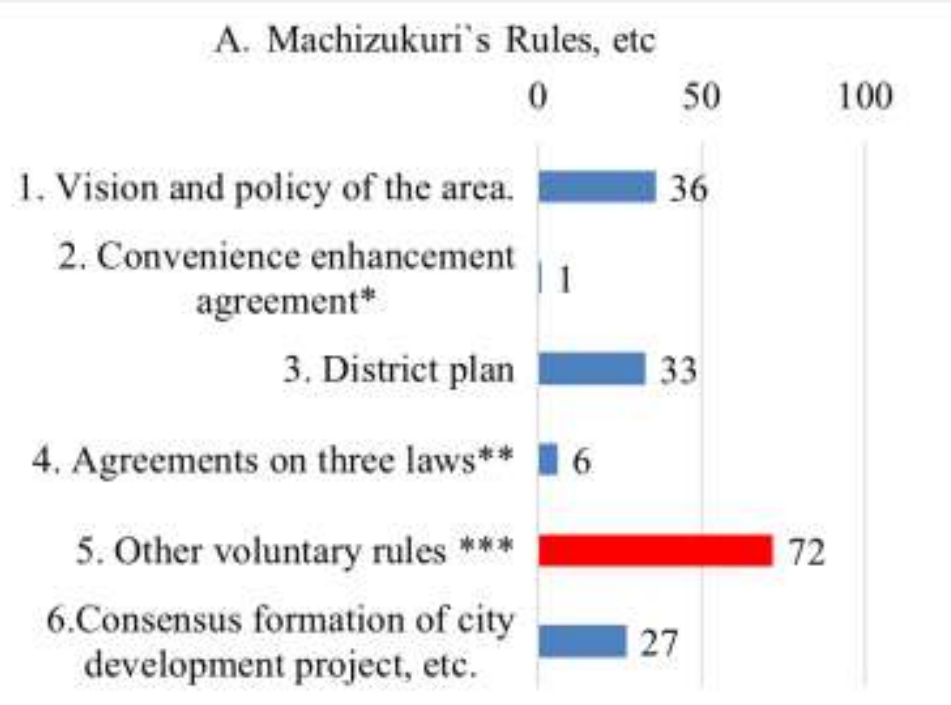

\footnotetext{
*Based on Act for special measures concerning urban regeneration.

**Building, greenery, landscape.

*** Landscape, signboard, community rules, etc.
}

Focusing on the detail of ABM activities, A (Machizukuri's rules) indicates that the sum of answers 2 to 5(convenience enhancement agreement (1), district plan (33), agreements on three laws(6), and other voluntary rules(72)) equate to more than 1.vision and policy of the area(36). This implies that there are many cases which do not start from a vision or policy for the area contrary to popular belief.

In Japan, there are three agreement systems under three laws: building, greenery, and landscape. Under these agreements, landowners within a certain area can make a treaty by unanimous agreement and obtain the approval of local government. Subsequently, the new landowner must follow the agreements. On the other hand, there is another system called a Convenience Promotion Agreement under the Act on special measures concerning urban regeneration. However, it can be concluded from the data that these legislative agreements are not much use.

The number of public events and commercial events is almost same, when arts, culture, and education (119) can be considered public events and the combination of Marche kiosks (26) and shops, restaurants, and open cafés (90) can be classed as commercial events. 


\section{$\underline{\text { B. Events and Activities }}$}

Figure 12. Main Activities at the Present Time (by Event and Activity)

B. Event, Activity

$\begin{array}{llll}0 & 50 & 100 & 150\end{array}$

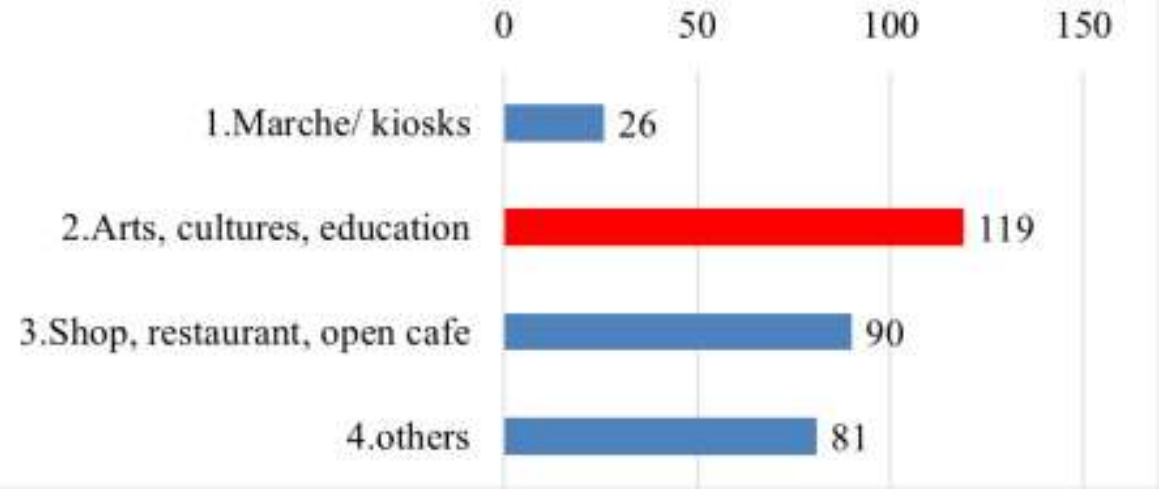

\section{Information Transmission}

Figure 13. Main Activities at the Present Time (by Information Transmission)

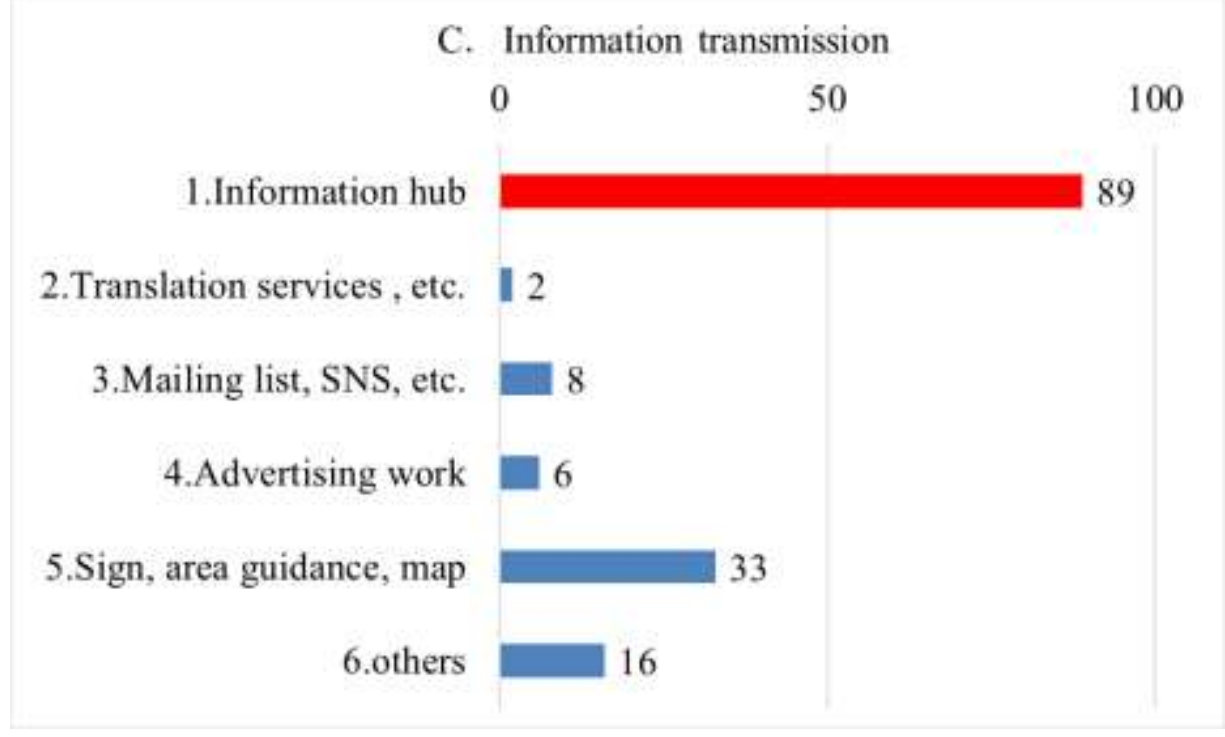

The figure for information hub (89) is highest in this category, and also includes the management of facilities for information transition, sign boards, pamphlets, mass communication or the internet, volunteer guides, etc. 
D. Disaster Prevention, Crime Prevention, and Providing a Sustainable Environment

Figure 14. Main Activities at the Present Time (by Disaster Prevention, Crime Prevention, and Providing a Sustainable Environment)

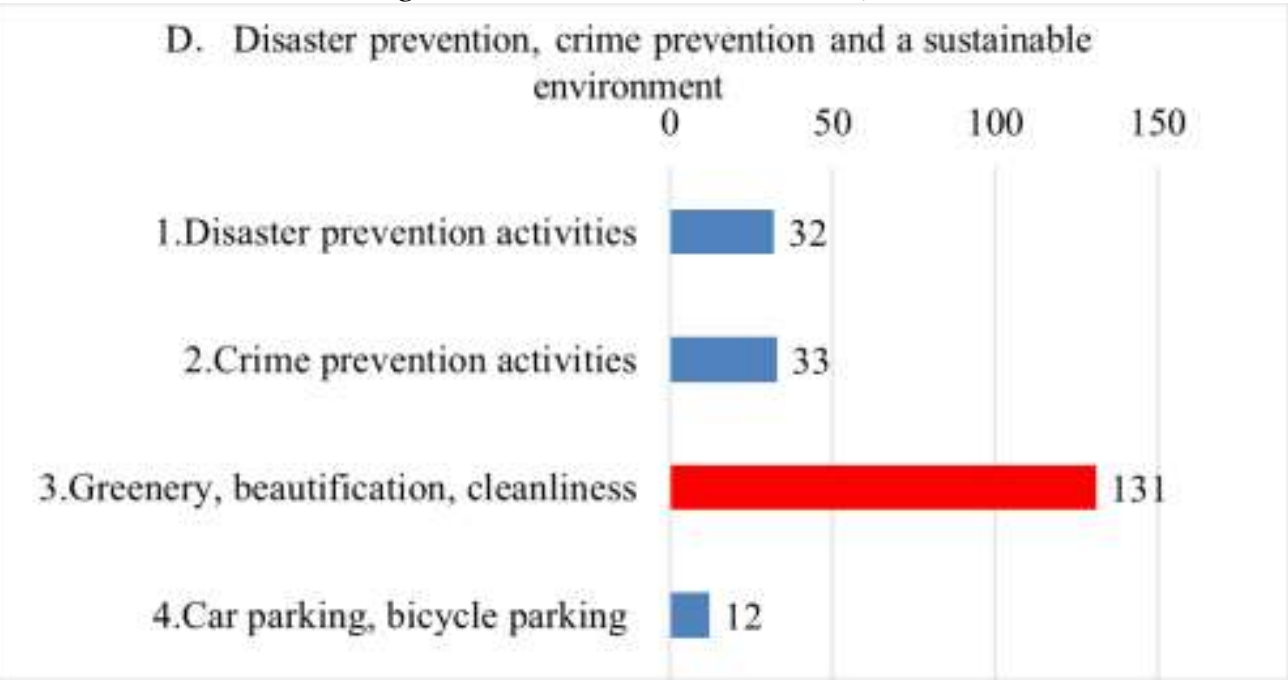

For the category $\mathbf{D}$ (disaster prevention, crime prevention, and providing a sustainable environment) greenery, beautification, and cleanliness (131) has the highest number.

$\underline{\text { E. Maintenance and Management of Public Facilities/Spaces }}$

Figure 15. Main Activities at the Present Time (by Maintenance and Management of Public Facilities/Spaces)

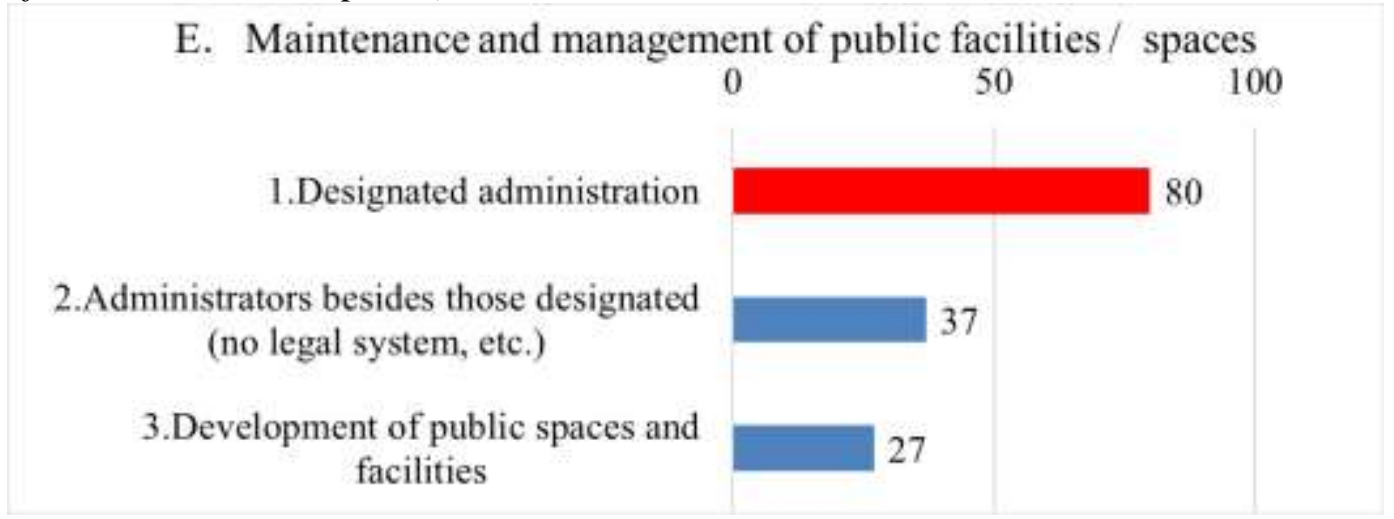

For the maintenance and management of facilities or spaces category, designated administration (80) was chosen most frequently in this group, followed by administration besides those designated (no legal system, etc.)(37) and development of public spaces and facilities (construction, renovation, reformation, high-quality improvement (27)). 
F. Improvement of Regional Attractiveness, Value, Convenience by the Public Use of Private Facilities

Figure 16. Main Activities at the Present Time (by Improvement of Regional Attractiveness, Value, Convenience by the Public Use of Private Facilities)

\section{$\mathrm{F}$. Improvement of regional attractiveness, value, convenience} by the public use of private facilities

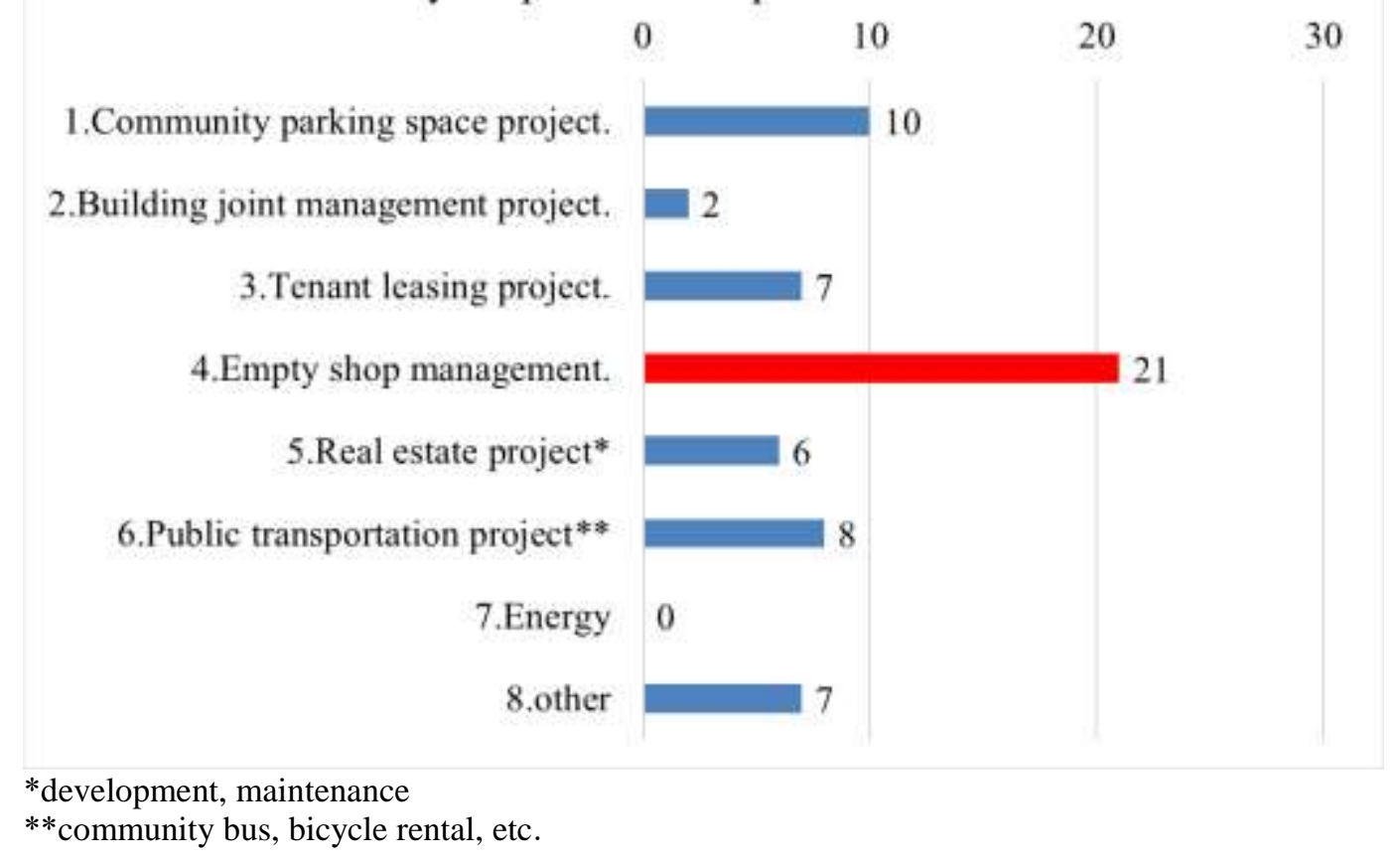

For the improvement of regional attractiveness, value, and convenience by the public use of private facilities, although the total figure is small, there is a variety of content. Among the categories, empty shop management has the highest number (21), with the community parking space project, tenant leasing project, real estate project, and public transportation project having roughly the same proportions.

\section{Organisational Characteristics}

\section{Corporate Formation}

The questionnaire was arranged in accordance with the juridical personality (if any) of each ABM organisation, and what kind of juridical personality they have. Answers from 2 to 8 in Figure 17) are organisations with juridical personality. 
Figure 17. Corporate Formation

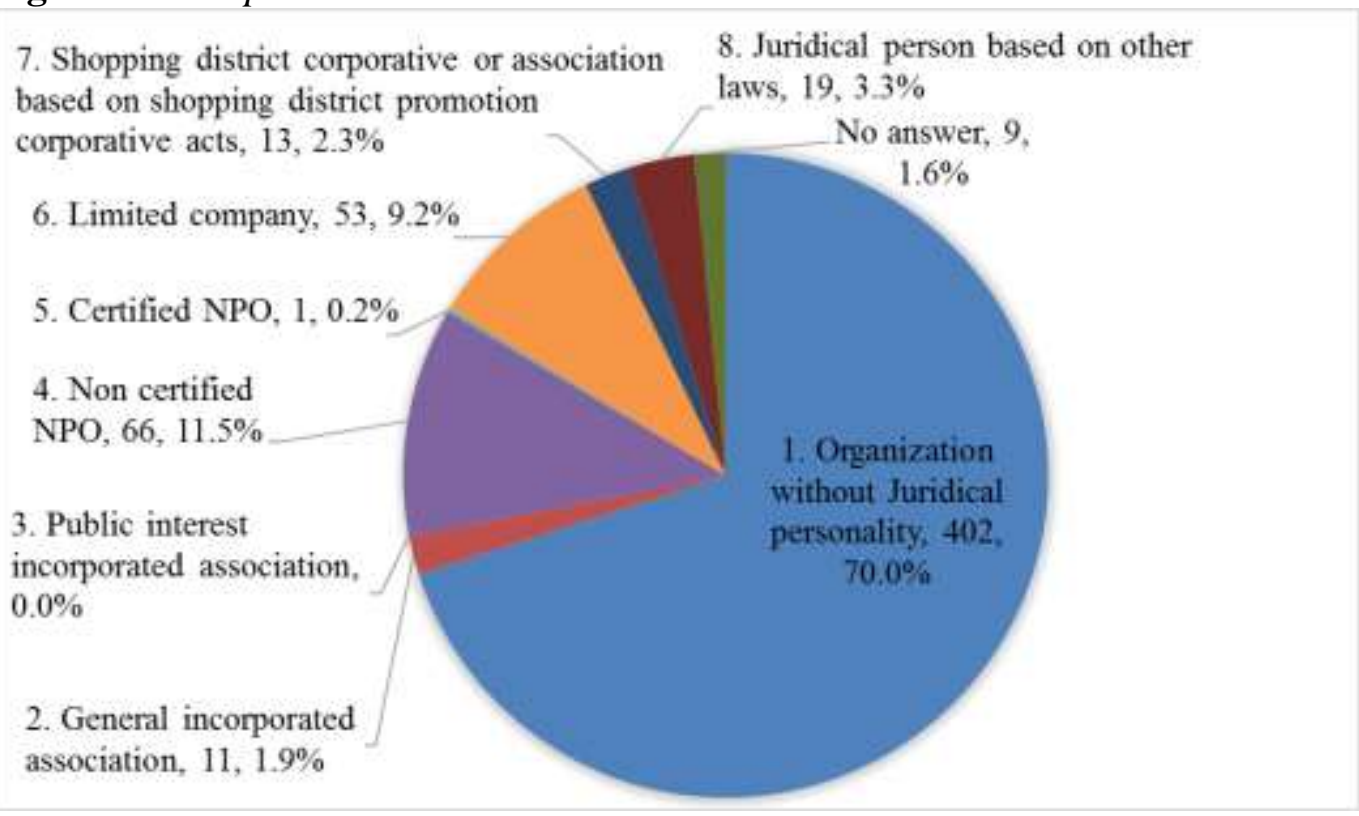

Figure 17, the number of ABM organisations without a juridical personality is highest at $70 \%$. It could be assumed that there are two reasons for this in that there are many organisations carrying out activities where a juridical personality is not required, and barriers exist concerning the cost and procedure to obtain one. According to the figures, some NPOs (66) and limited companies exist (53), but these only account for approximately $10 \%$ of all ABM organisations. Only $1.9 \%$ (11) are general incorporated associations, there is no public interest incorporated association, and only one certified NPO is an ABM entity (approximately 0\%). This shows that these certification systems are virtually unutilised and ineffective. Shopping district cooperatives or associations based on the Shopping District Promotion Cooperatives Act number only 13 (2.3\%). It could therefore be implied that such organisations are not responsible for ABM activities or local government does not recognise them as $\mathrm{ABM}$ organisations. 
Office Possession of an ABM Organisation (Administrative Office)

\section{$\underline{\text { Administrative Office Possession }}$}

Figure 18. Administrative Office Possession

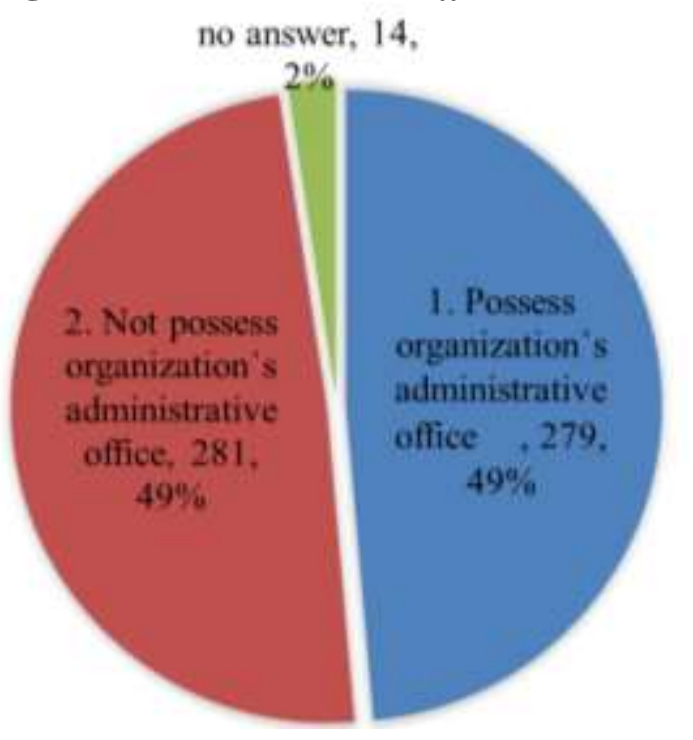

Figure 18 shows the possession of an ABM administrative office.The results show that about half (49\%) possess their own administrative office.

\section{Employment Resources}

Figure 19. Employment Resources

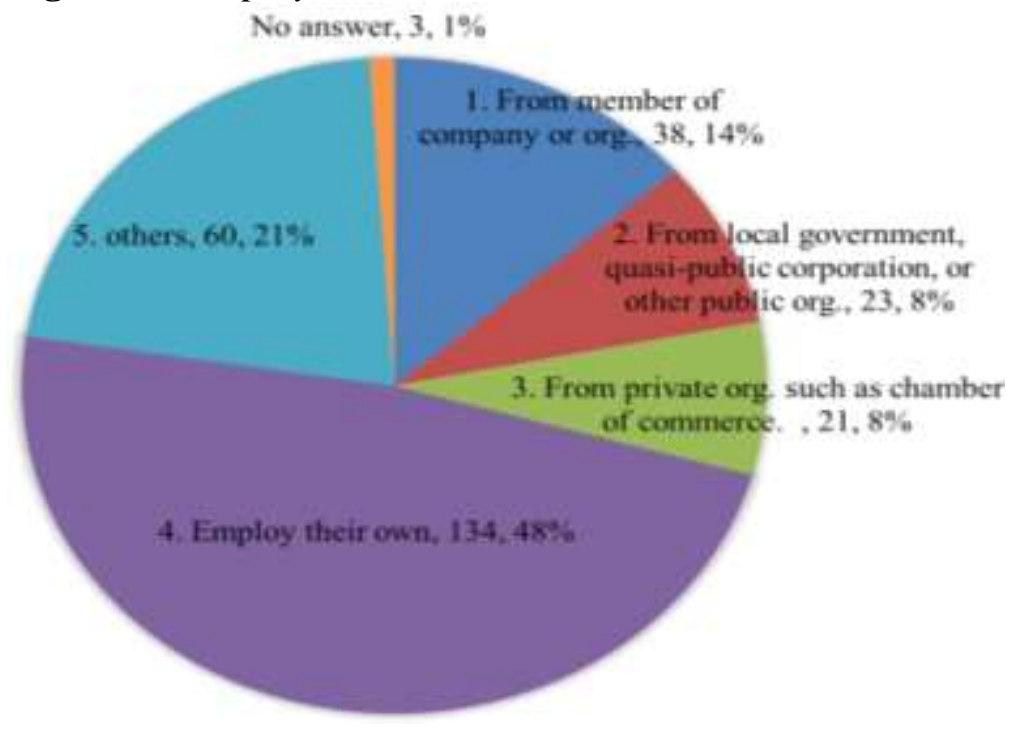

Figure 19 provides the research results for $\mathrm{ABM}$ organisations which answered that they possess their own administrative office previously (Figure 18) concerning staff resources. The results indicate that almost half $(48 \%)$ of 
organisations have employed staff from their own resources and approximately $30 \%$ are staff dispatched from other organisations.

\section{Sources of Income}

Table 11. Sources of Income (Multiple Answers)

\begin{tabular}{|l|c|c|c|}
\hline Contents & Answers & $\begin{array}{c}\text { Composition } \\
\text { Ratio }\end{array}$ & $\begin{array}{c}\text { Ratio } \\
\text { from } \\
\text { Answered } \\
\text { Orgs. }\end{array}$ \\
\hline 1. Membership fee or landowner support & 233 & $27.1 \%$ & $40.6 \%$ \\
\hline $\begin{array}{l}\text { 2. Revenue from activity in Group B (event, } \\
\text { activity) }\end{array}$ & 104 & $12.1 \%$ & $18.1 \%$ \\
\hline $\begin{array}{l}\text { 3. Revenue from activity in Group } \\
\text { C (information transmission) }\end{array}$ & 20 & $2.3 \%$ & $3.5 \%$ \\
\hline $\begin{array}{l}\text { 4. Revenue from activity in Group D (crime } \\
\text { prevention, disaster protection, providing } \\
\text { a sustainable environment) }\end{array}$ & 8 & $0.9 \%$ & $1.4 \%$ \\
\hline $\begin{array}{l}\text { 5. Revenue from activity in Group E } \\
\text { (maintenance and management of public } \\
\text { facilities/public spaces) }\end{array}$ & 52 & $6.0 \%$ & $9.1 \%$ \\
\hline $\begin{array}{l}\text { 6. Revenue from activity in Group F } \\
\text { (improvement of regional attractiveness, } \\
\text { value or convenience by the public use of } \\
\text { private facilities) }\end{array}$ & 26 & $3.0 \%$ & $4.5 \%$ \\
\hline $\begin{array}{l}\text { 7. Local authority support such as a subsidy } \\
\text { or consignment fee }\end{array}$ & 322 & $37.4 \%$ & $56.1 \%$ \\
\hline 8. Donations & 43 & $5.0 \%$ & $7.5 \%$ \\
\hline 9. Other & 860 & $100.0 \%$ & $9.1 \%$ \\
\hline \hline Total & 35 & $6.1 \%$ \\
\hline \hline no answer(including no sources of income) & & \\
\hline
\end{tabular}

Research concerning sources of income with multiple answers is shown in Table 11. The highest number of ABM organisations chose their source of income as coming from 7. local authority support such as a subsidy or consignment fee, accounting for more than half $(56 \%)$. This is followed by 1 . ABM organisations receiving fees from members or landowner support (40.6\%). ABM organisations receiving revenue from activities numbered (2.-6.) are insignificant at $210(36.6 \%)$ when combined together and eliminating duplication. The organisations receiving the majority of their income from activities could mean that they are financially independent and do not rely much on others. Therefore, comparing organisations where activities do not represent their main source of income, it can be said that they are self-sustaining from the financial resources viewpoint. In addition, approximately $6 \%$ of all organisations could not give an answer. This figure includes those without any income source, and it can be said that there are very few such ABM organisations. 
Among the many ABM activities shown in Table 8, only 61 organisations operate $\mathbf{F}$ (the improvement of regional attractiveness, value, or convenience by the public use of private facilities at the present time)(Figure 16). However, the number of organisations whose main source of income for activity $\mathbf{F}$ is comparatively high (26), as shown in Table 11. Therefore, it could be implied that activity $\mathbf{F}$ is advanced, and difficult to operate, but could provide income with high possibility. On the other hand, $\mathbf{C}$ information transmission, and $\mathbf{D}$ disaster prevention, crime prevention, and providing a sustainable environment provide income hardly, although there are many organisations carrying out these activities. Machizukuri's rules are not included in the questionnaire choices since they cannot be an income source.

Frequency of Activities

Figure 20. Frequency of Activities

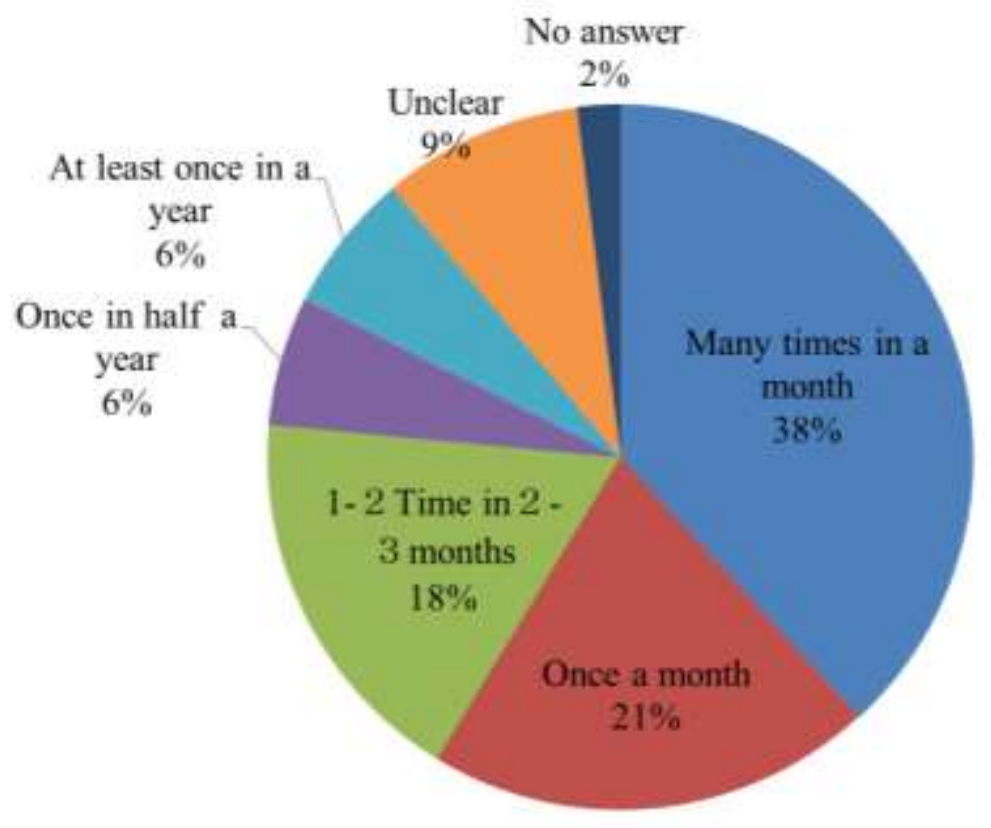

This study examined the data on the frequency of all ABM organisational activities (sum of all the main activities A-F in Figure11.-16., inferior activities, meetings, etc.). The results indicate that a frequency of at least $50 \%$ represents an activity occurring more than once a month (Figure 20).

\section{Effects}

\section{Effect of Activities}

The effects of all ABM activities are evaluated by representatives of local government in categories 1 - 10 ranked I to V below.

1. Effect on a suitable or beautiful landscape 
2. Effect of enhanced visitor numbers (customers, passengers, travellers, tourists, etc.)

3. Real estate effect (to reduce empty buildings, shops, or vacancy rates, to increase rent, etc.)

4. Effect on economic vitalisation (to increase consumption, merchandise, or employment)

5. Effect on disaster prevention, crime prevention, or public safety

6. Effect of enhanced community power, mutual understanding, or networking

7. Effect of reduced financial burden such as lower costs for maintenance of public facilities

8. Effect of public awareness of the area or recognition of ABM activities

9. Effect on regional competition (to increase workers or population, crisis management)

10. Other

Rank (10 categories above): I. Huge effect, II. Marked effect, III. Not much effect, IV. No effect, V. Do not know or organisation does not intend to obtain this effect.

More than $90 \%$ of the answers indicated the effectiveness of 6.enhanced community power, mutual understanding or networking. Over $70 \%$ considered the following to be effective: 1 . a suitable or beautiful landscape, 2 . enhanced visitor numbers (customers, passengers, travellers, tourists, etc.), 8. public awareness of the area or recognition of $\mathrm{ABM}$ activities, and 5. disaster prevention, crime prevention, or public safety. It could be considered that the effect of area management is generally highly valued. Three effects particularly easy to increase with $\mathrm{ABM}$ are: 6.enhanced community power, mutual understanding, or networking; 1.a suitable or beautiful landscape; and 2.enhanced visitor numbers. These are followed by 8.public awareness of the area or recognition of $A B M$ activities; 5.disaster prevention, crime prevention, or public safety; and 4.economic vitalisation, orderly. Regarding 7.reducing the financial burden such as lowercosts for maintenance of public facilities, 9.regional competitiveness, and 3.real estate effect, the answers were "I. huge effect" 7.(43), 9.(17), and 3.(16). This indicates that there are many instances of huge effects being produced in these categories. 
Figure 21. Effects of ABM Activities (Ranked I-V)

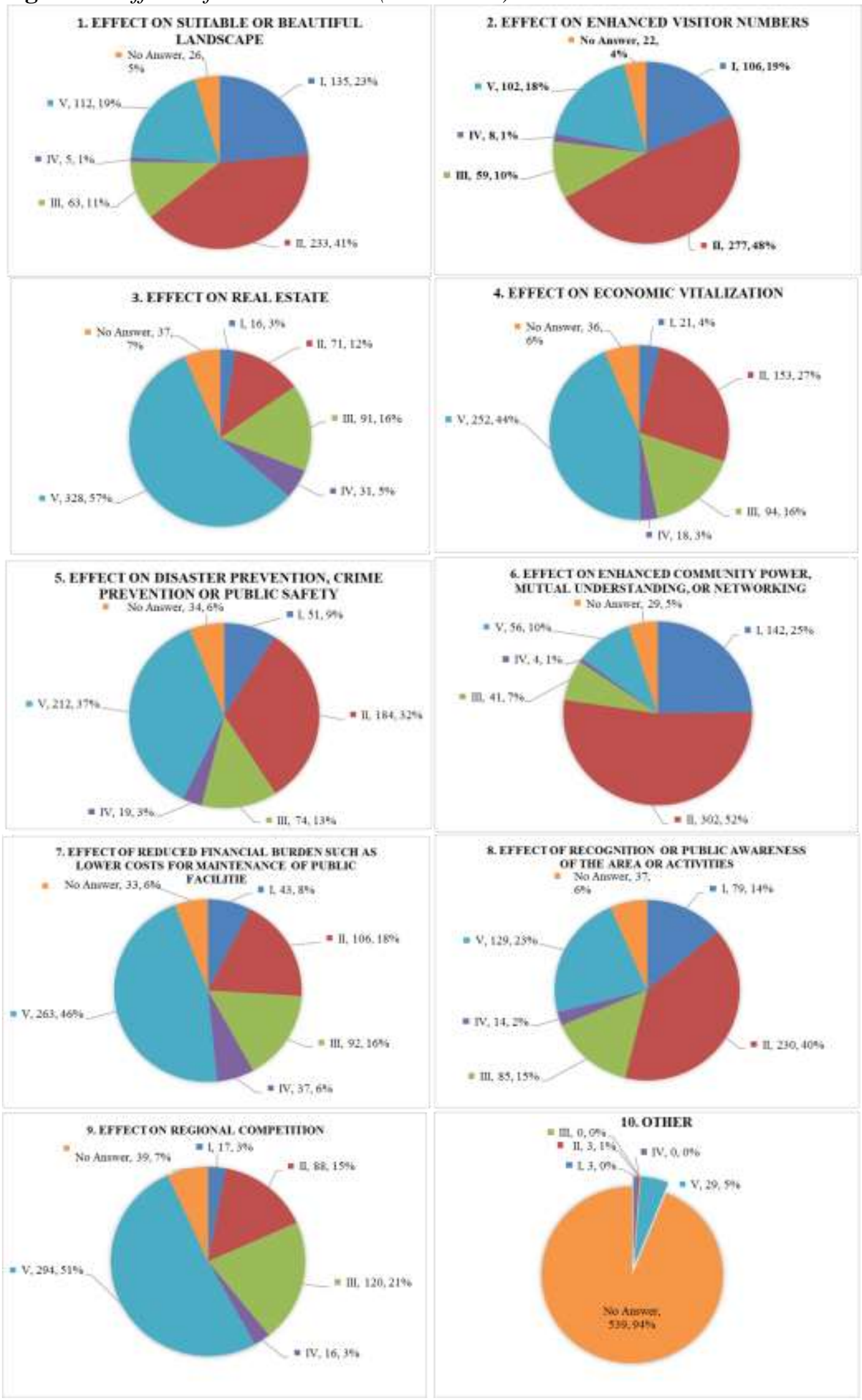


The evaluation of nine effects in descending order could be arranged as follows:

6. Effect of enhanced community power, mutual understanding or networking

2. Effect of enhanced visitor numbers (customers, passengers, travellers, tourists, etc.)

1. Effect on a suitable or beautiful landscape

8. Public awareness of the area or recognition of ABM activities

5. Disaster prevention, crime prevention, or public safety

4. Effect on economic vitalisation

7. Effect of reduced financial burden such as lower costs for maintenance of public facilities

9. Effect on regional competition

3. The real estate effect

Although these evaluations are subjective since they are provided by representatives of local government, they could be considered valuable since no other surveys have evaluated the various effects of ABM on a nationwide by unified basis.

Figure 22. Effect of Activities with the Answer "Huge Effect" and "Marked as Effective" in Total (from Figure 21)

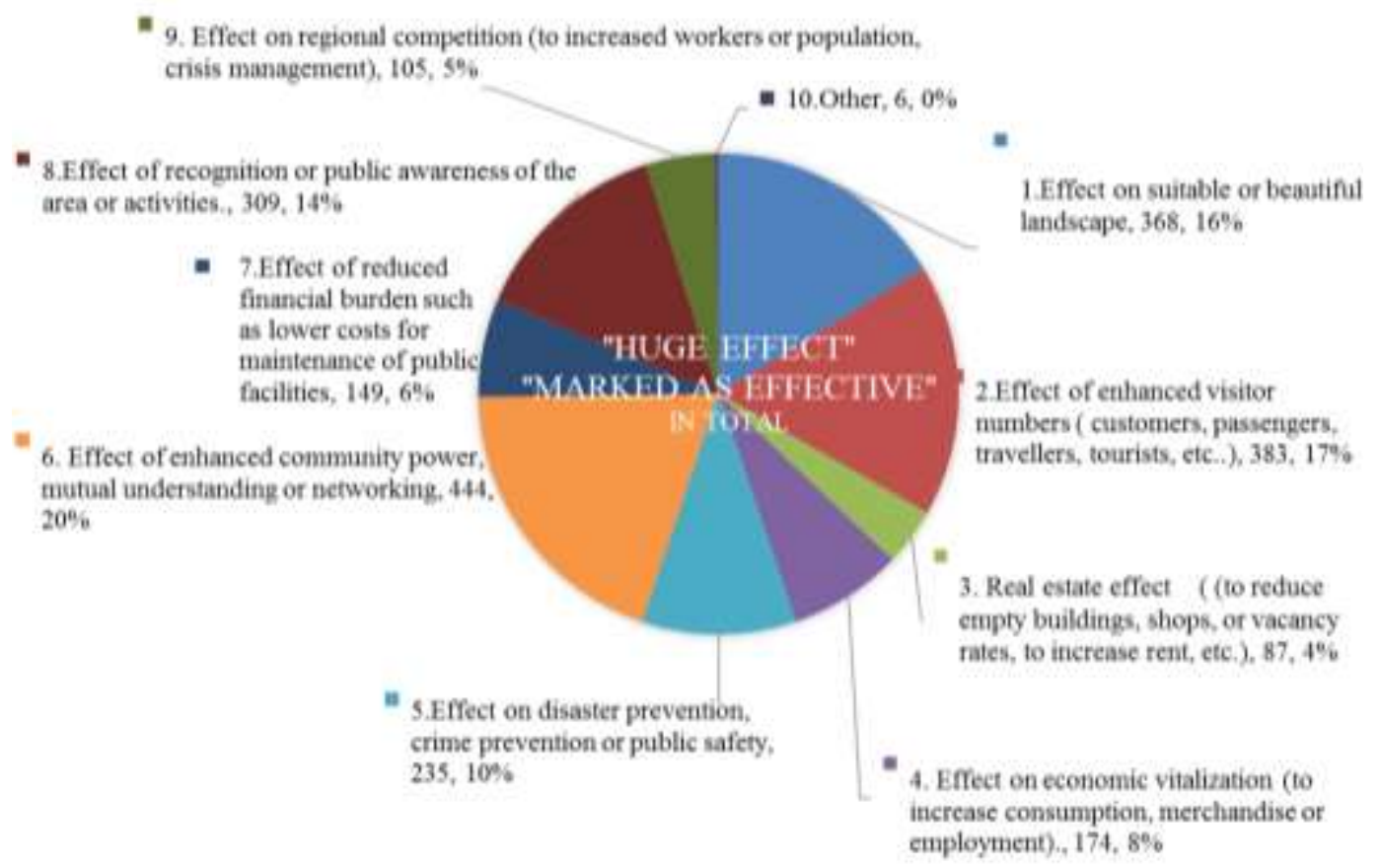

From 10 effects, the answers "I. Huge effect" and "II. Marked as effective" in Figure 22 shows that the average for 1 to 9 is $11 \%$. The effects with a higher than average percentage are: 1 . effect on a suitable or beautiful landscape, 2. effect of enhanced visitor numbers (customers, passengers, travellers, tourists, etc.), 6.effect of enhanced community power, mutual understanding, or networking, and 8.public 
awareness of the area or recognition of $\mathrm{ABM}$ activities.

\section{The Greatest Effect}

\section{Figure 23. The Greatest Effect (among 10 Effects-One Answer)}

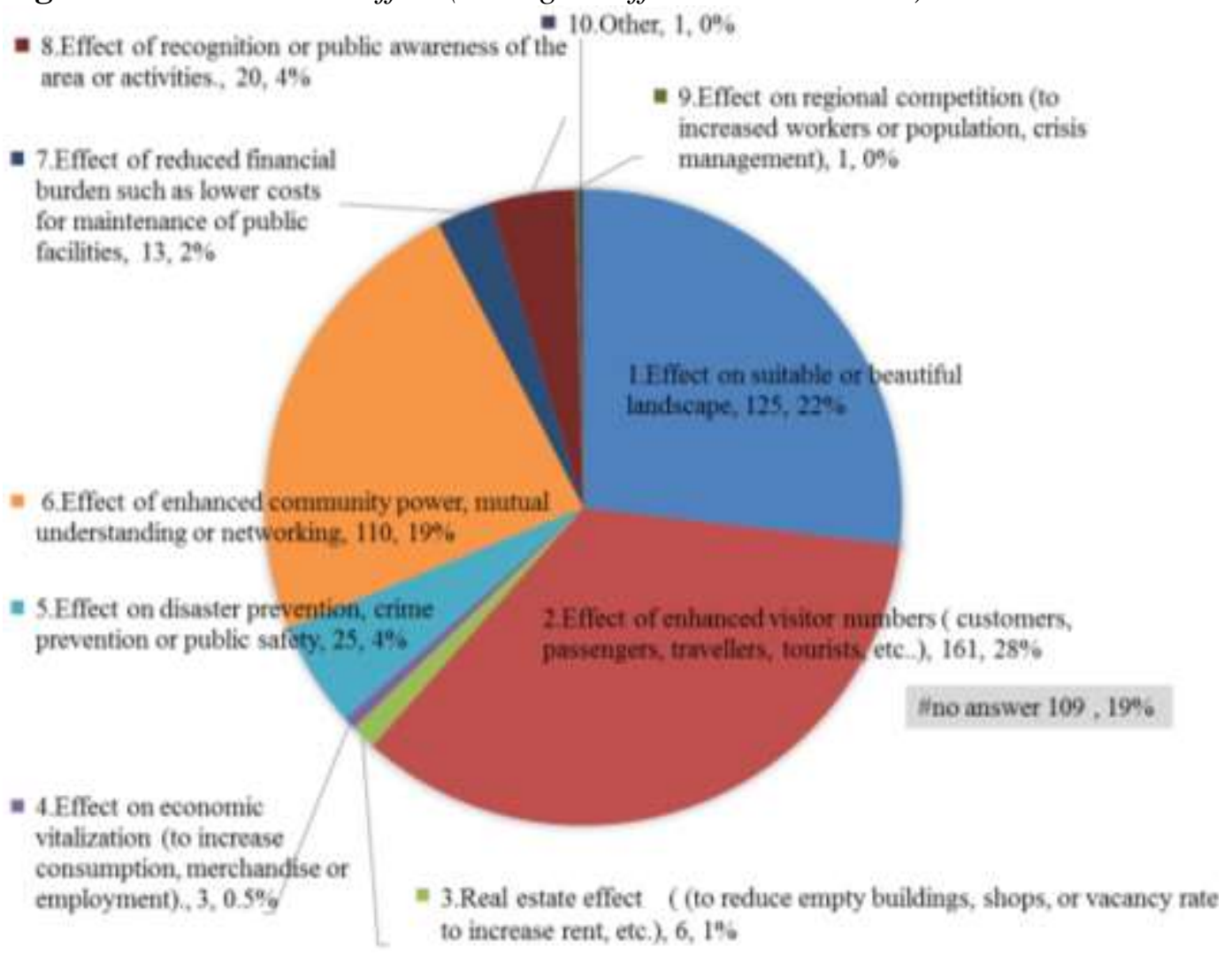

In this research, questionnaires were provided to the same representatives of local government concerning the greatest effect of each ABM organisation, from the 10 effects shown in Figure 23. The three highest effects are: 2.effect of enhanced visitor numbers (customers, passengers, travellers, tourists, etc.) $(28 \%)$, 1.effect on a suitable or beautiful landscape (22\%), and 6.effect of enhanced community power, mutual understanding, or networking $(19 \%)$, in descending order. 


\section{$\underline{\text { Spillover Effect }}$}

Figure 24. Spillover Effect

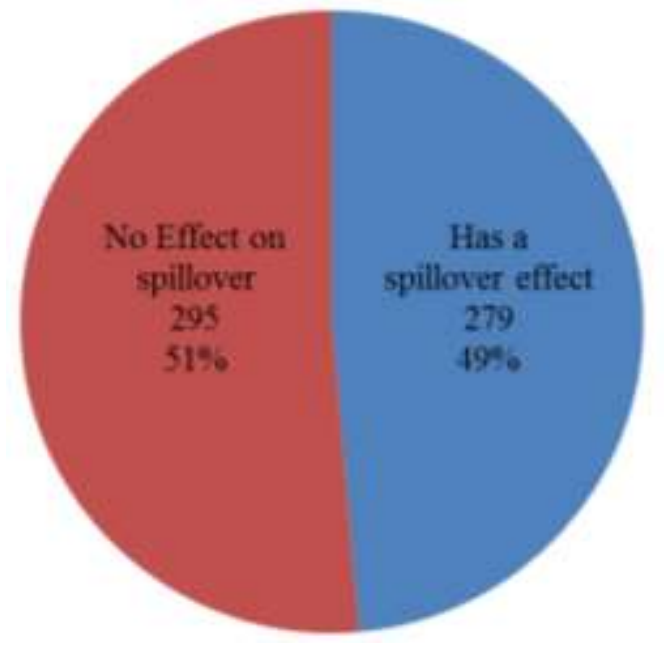

The ABM questionnaire also asked the same representatives of local government whether or not the 10 effects categories set out previously spillover to outside the area where each ABM organisation operates. Approximately half of the ABM organisations were found to have a spillover effect (Figure 24).

\section{Figure 25. Spillover Effect in Detail}

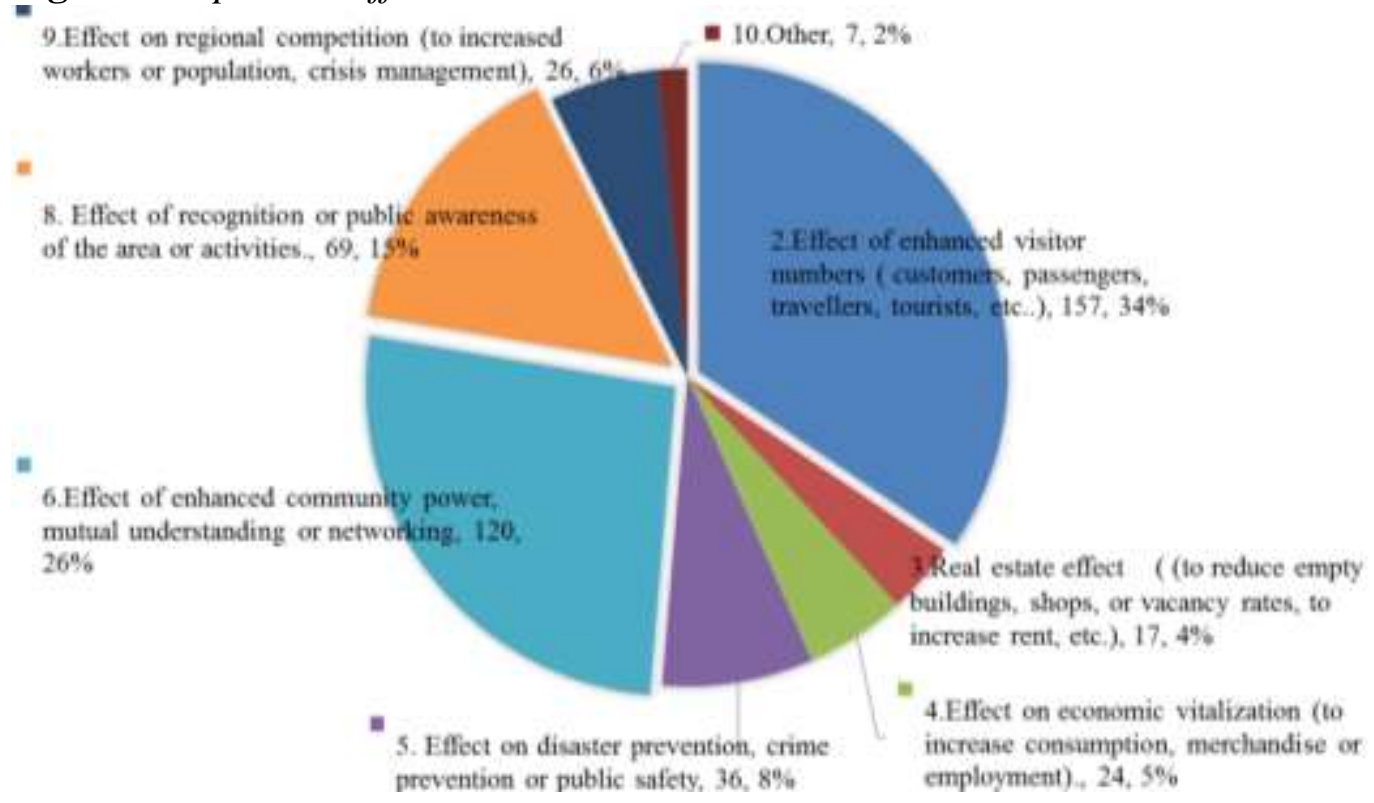

In addition, the spillover effect in Figure 24 can be divided into 10 categories as indicated, and their composition ratio is shown in Figure 25.; 2.effect of enhanced visitor numbers (customers, passengers, travellers, tourists, etc.), 6.effect of enhanced community power, mutual understanding, or networking, and 8.public awareness of the area or recognition of $\mathrm{ABM}$ activities are the main effects of 
spillover. In particular, effect 2.has the highest ratio in Figure 25, and the ratio of the answers "has a spillover effect" to the combined number of the answers "I. huge effect" and "II. marked as effective" is high (41\%). Therefore, it can be implied that effect 2.is the easiest way to obtain a spillover effect, followed by effects 6 .and 8 .

\section{Motivating Effect of other ABM Organisations}

Figure 26. Motivating Effect of other ABM Organisations

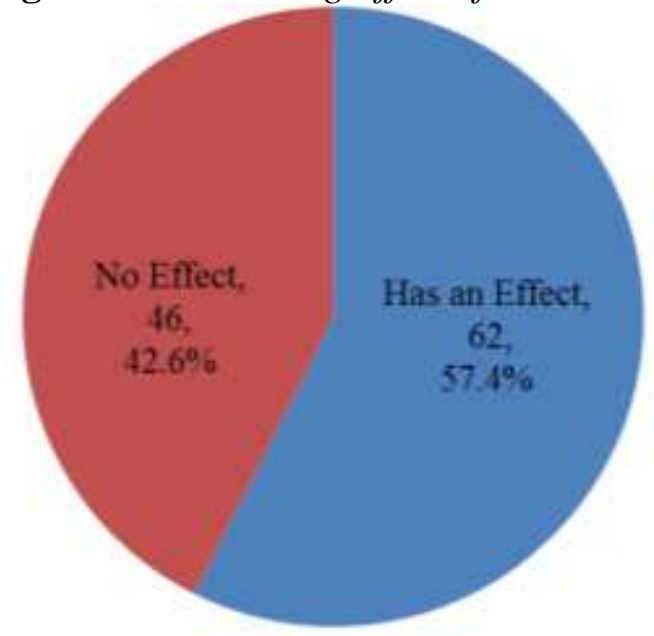

* The answer are from only $19 \%$ of all ABM

Concerning the 10 effects categories, $\mathrm{ABM}$ surveys also have a question on another kind of spillover effect, namely "a motivating effect on other ABM organisations".This means that ABM activities motivate the establishment of new $\mathrm{ABM}$ organisations, or enhance activities of other ABM organisations. More than half of the organisations responded with the answer "has a motivating effect on other ABM organisations". However, it should be noted that about $80 \%$ did not provide an answer.

Problems for ABM Organisations

Table 12. Problems for ABM Organisations

\begin{tabular}{|l|c|c|}
\hline Title & Answers & Ratio from answered orgs. \\
\hline Finance & 160 & $27.9 \%$ \\
\hline Human resources & 204 & $35.5 \%$ \\
\hline Awareness & 42 & $7.3 \%$ \\
\hline System & 29 & $5.1 \%$ \\
\hline Other & 29 & $7.5 \%$ \\
\hline No answer & 273 & $47.5 \%$ \\
\hline
\end{tabular}


Figure 27. Problems for ABM Organisations

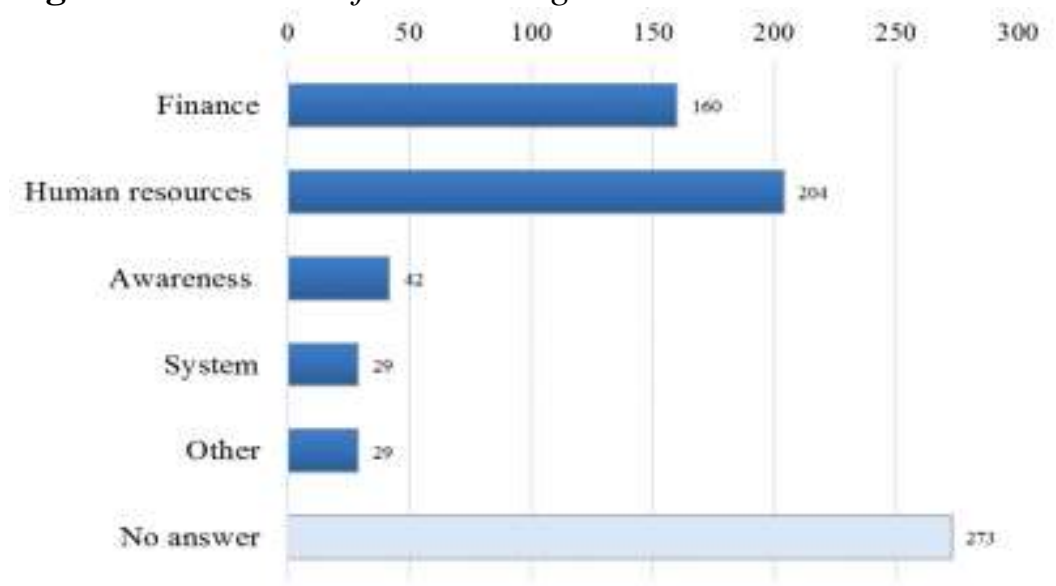

The aggregate results from the questionnaires concerning the existing or possible problems faced by ABM organisations are shown in Table 12 and Figure 27. The proportion oforganisations with problems and those without (no answer) was roughly half and half. Many ABM organisations have problems concerning finance (160) or human resources (204). In addition, from the ABM questionnaires, the financial problems appear to relate to expenditure on human resources and employment as well as the costs involved in the implementation of a wide range of projects and business activities such as new events, a shortage of financial resources for maintenance and repair due to ageing facilities. There are two kinds of problems involving human resources; one concerns the management or employment of adequate staff who can proactively engage in ABM activities or administration. Another relates to the spread of ABM, such as the ageing of members, lack of successors, and generational changes. This means it may be problems with cooperation, attendance, awareness, etc. There are also likely to be system problems relating to the use of public facilities. For example, there is a complicated permission process involving police or administrators when using public facilities such as roads for events or property installation, etc., as well as system limitations for operation and the burden of occupancy charges. Moreover, there are difficulties with the possession of a juridical personality and problems regarding taxation on the profits of $A B M$ organisations profits. Other problems include stagnation because too much time has passed since the activities began.

\section{Cross Analysis: Relationship between Activities and Organization Style}

A cross analysis of some data is made with the aim of advising on the functional improvement of ABM. In this sense, the purpose of the following three paragraphs is: 1) to clarify what kind of organisational style is suitable for active and wide-ranging ABM activities; 2) to clarify what kind of organisational style is suitable forobtaining income; and 3) to clarify the relationship between organisational style and financial problems. 
The Average Number of Activity Types by Corporate Formation

Table 12. The Average Number of Activity Types by Corporate Formation

\begin{tabular}{|l|c|}
\hline Title & Average Number \\
\hline Non-JDP & 1.79 \\
\hline Limited companies & 2.60 \\
\hline NPO & 2.52 \\
\hline
\end{tabular}

The above analysis relates to the number of activity types by corporate formation. Non-JDP means organisations without juridical personalities in Figure 17. Only three corporate formations with comparatively greater numbers are analysed in this chapter and shown in Table 12. From the analysis, it can be said that organisations with juridical personalities are more active and wide-ranging concerning ABM activities than those without.

The Average Number of Activity Types by Administrative Office Possession

Table 13. The Average Number of Activity Types by Administrative Office Possession

\begin{tabular}{|l|c|}
\hline Title & Average Number of Activity Types \\
\hline Possess an administrative office & 2.33 \\
\hline Do not possess an administrative office & 1.63 \\
\hline Average & 1.98 \\
\hline
\end{tabular}

Table 13 shows the number of activity types by administrative office possession. From this table, it can be said organisations possessing administrative offices are more active and wide-ranging concerning ABM activities than those without.

\section{Cross Analysis: Relationship between Income Sources and Organisational Style}

$\underline{\text { Relationship Between Income Sources and Corporate Formations }}$

Table 14. The Ratio of Income Sources by Corporate Formation

\begin{tabular}{|l|c|c|c|}
\hline Title & $\begin{array}{c}\text { Non- } \\
\text { JDP }\end{array}$ & $\begin{array}{c}\text { Limited } \\
\text { Companies }\end{array}$ & NPO \\
\hline Membership fee or landowner support & $40.8 \%$ & $15.1 \%$ & $52.2 \%$ \\
\hline Revenue from activity in Group B & $10.9 \%$ & $32.1 \%$ & $38.8 \%$ \\
\hline Revenue from activity in Group C & $1.5 \%$ & $7.5 \%$ & $10.4 \%$ \\
\hline Revenue from activity in Group D & $0.7 \%$ & $3.8 \%$ & $3.0 \%$ \\
\hline Revenue from activity in Group E & $3.2 \%$ & $28.3 \%$ & $26.9 \%$ \\
\hline Revenue from activity in Group F & $0.7 \%$ & $34.0 \%$ & $6.0 \%$ \\
\hline $\begin{array}{l}\text { Local authority support such as a subsidy or } \\
\text { consignment fee }\end{array}$ & $59.5 \%$ & $43.4 \%$ & $53.7 \%$ \\
\hline Donations & $7.7 \%$ & $0.0 \%$ & $10.4 \%$ \\
\hline Other & $9.5 \%$ & $9.4 \%$ & $3.0 \%$ \\
\hline
\end{tabular}


Table 14 shows the ratio of income sources by corporate formation. The figures in the table represent the percentage of organizations with an income source to the total corporate formation. Concerning the three main sources of income shown in Table 14, it can be implied that non-JDPs and NPOs are more likely to have membership fees or landowner support than limited companies, and limited companies and NPOs tend to have more revenue from activities than non-JDPs. Whereas there is not so much difference among corporation formations regarding local authority support.

$\underline{\text { Relationship Between Income Sources and Administrative Office Possession }}$

Table 15. The Ratio of Income Sources by Administrative Office Possession

\begin{tabular}{|l|c|c|}
\hline Title & $\begin{array}{c}\text { Possess an } \\
\text { administrative office }\end{array}$ & $\begin{array}{c}\text { Do not possess an } \\
\text { administrative office }\end{array}$ \\
\hline $\begin{array}{l}\text { Membership fee or landowner } \\
\text { support }\end{array}$ & $40.5 \%$ & $41.3 \%$ \\
\hline Revenue from activity in Group B & $23.7 \%$ & $13.5 \%$ \\
\hline Revenue from activity in Group C & $5.4 \%$ & $1.8 \%$ \\
\hline Revenue from activity in Group D & $1.4 \%$ & $1.4 \%$ \\
\hline Revenue from activity in Group E & $14.7 \%$ & $3.2 \%$ \\
\hline Revenue from activity in Group F & $8.2 \%$ & $1.1 \%$ \\
\hline $\begin{array}{l}\text { Local authority support such as } \\
\text { a subsidy or consignment fee }\end{array}$ & $61.3 \%$ & $53.4 \%$ \\
\hline Donations & $6.8 \%$ & $8.5 \%$ \\
\hline Other & $10.4 \%$ & $8.2 \%$ \\
\hline
\end{tabular}

Table 15 shows a cross analysis of income sources and administrative office possession for ABM organisations, indicating that no significant difference exists between an $\mathrm{ABM}$ possessing an administrative office or one without in obtaining membership fees or landowner and local authority support. However, organisations possessing an administrative office tend to receive more revenue from activities than those without.

Cross Analysis: Relationship between Financial Problems and Organisational Style

$\underline{\text { Relationship Between Financial Problems And Corporate Formation }}$

Table 16. The Ratio of Problems for ABM Organisations by Corporate Formation

\begin{tabular}{|l|c|c|c|c|}
\hline Title & Non-JDP & $\begin{array}{c}\text { Limited } \\
\text { companies }\end{array}$ & NPO & Average \\
\hline Finance & $22.9 \%$ & $47.2 \%$ & $43.9 \%$ & $28.1 \%$ \\
\hline Human resources & $36.3 \%$ & $28.3 \%$ & $33.3 \%$ & $35.5 \%$ \\
\hline Awareness & $8.0 \%$ & $5.7 \%$ & $9.1 \%$ & $7.9 \%$ \\
\hline System & $4.0 \%$ & $3.8 \%$ & $7.6 \%$ & $4.9 \%$ \\
\hline
\end{tabular}


Table 16 shows the tendency towards problem types for ABM organisations by corporate formation. The figure shown represents the percentage of corporate formations experiencing a particular problem type compared to the total number of organisations. Concentrating on the financial problems in alignment with the topic of this chapter, it could be implied that organisations with juridical personalities tend to have more financial problems than those without, although organisations with juridical personalities are likely to receive income from a greater variety of sources as mentioned "Relationship between income sources and corporate formations".

$\underline{\text { Relationship between Financial Problems and Administrative Office Possession }}$

Table 16. The Ratio of Problems for ABM Organisations by Administrative Office Possession

\begin{tabular}{|l|c|c|}
\hline Title & $\begin{array}{c}\text { Possess an Administrative } \\
\text { Office }\end{array}$ & $\begin{array}{c}\text { Do not Possess an } \\
\text { Administrative Office }\end{array}$ \\
\hline Finance & $38.4 \%$ & $17.4 \%$ \\
\hline Human resources & $34.4 \%$ & $36.7 \%$ \\
\hline Awareness & $6.8 \%$ & $8.2 \%$ \\
\hline System & $7.2 \%$ & $3.2 \%$ \\
\hline
\end{tabular}

Table 16 shows the kind of problems likely to occur in ABM organisations possessing an administrative office and those without. Organisations possessing an administrative office are shown to be more likely to experience financial problems than those without, although the former tend to receive more revenue from activities as mentioned in Table 15.

From a cross analysis of the three preceding paragraphs, if an ABM organisation intends to operate a wide rang of activities, it is advisable to have both a juridical personality and an administrative office. In addition to that, as wide-ranging activities need more income generally, having juridical personalities and administrative office is also recommendable to get more revenue, especially revenue from $\mathrm{ABM}$ activities. However, obtaining the juridical personality and an administrative office tends to invite financial problems, because operating costs are higher.

\section{Conclusion}

Among the objectives of area management defined abstractly as "to improve and enhance the life environment and local value for the area", enhancing the number of visitors or customers and providing a beautiful landscape are the most important, followed by enhancing community power, mutual understanding, or networking, according to the results of the survey. The main motivations for starting ABM are similar to the objectives, namely strengthening networks and connections, improving quality of life, and orderly economic improvement . Regarding initiatives at the start of $\mathrm{ABM}$, although there are many from the 
private sector, considerable amount of public initiatives also exist. This is consistent with the answers in "Organisational motivation for starting ABM activities" which indicate that there is considerable motivation from the viewpoint of the government for starting ABM, such as landscape improvements, security, and regional economics as well as competition between areas. Most ABM organisations were established or evolved after 2000. This means that the history of ABM is less than twenty years old. ABM is a relatively new activity for coping with Japan's recent socio-economic and environmental changes.

There is a larger variety of ABM activities than objectives and many ABM organisations carry out a wide variety of activities. As mentioned above, ABM organisations are concerned with three main objectives, although they also have certain other secondary aims. Therefore, in order to achieve such objectives, they operate activities according to the particular situation in each area. In this respect, it can be implied that ABM organisations are characterised not by the activities they operate, but by their objectives. This conclusion is consistent with the definition of ABM contained in "Introduction". Therefore, concerned parties of $\mathrm{ABM}$, such as people who want to start the process or local governments who want to support it, should not focus so much on the activities of $\mathrm{ABM}$, but on the objectives behind such activities.

In addition, the range of $\mathrm{ABM}$ activities is wider in commercial areas than residential. In commercial areas, the bigger the city size, the wider the range tends to be, but there is no such tendency in residential areas.

Regarding the characteristics of each ABM activity type, events and activities are the most numerous and have a high affinity with other types. Even though they may not operate during the beginning phase, they are easy to perform later. Events and activities generate more income compared to other activities. In this respect, it could be implied that events and activities are easy to operate and can possibly provide income. Therefore, it is advisable to start by choosing events and activities for an ABM organisation facing financial problems (which is one of the common issues for ABM organisations).

Information transmission is easy to match with other activities but generates a small percentage of revenue. Therefore, it characteristically tends to perform a subsidiary role.

As for the characteristics of the public use of private facilities, the contents of this type of activitiy are various. This activity is difficult to operate but highly likely to generate income. Therefore, it could be implied that this type of activity is at the advanced level.

Machizukuri's rule is chosen by many ABM organisations but is less likely to be combined with other activities. Moreover, if not operated during the beginning phase, it is less likely to be established during the later stages. This is a unique characteristic which is significantly different from other activity types. In this sense, if an ABM organisation needs to operate Machizukuri's rule, it should aim to do so from the beginning, as commencing the process with other easier activities is not advised.

Though ABM organisations without juridical personalities are common, this is thought to be as a result of an intricate and complicated corporate 
formation system for acquiring and managing a juridical personality.

For concerned parties of $\mathrm{ABM}$ who intend their organizational activities to be more wide-ranging, the possession of a juridical personality and administrative office is advisable in order to carry out more activities and obtain greater revenue especially from $\mathrm{ABM}$ activities. However, such organisations need to understand that a juridical personality and administrative office can sometimes incur financial problems.

From the above discussion, it may be concluded that ABM organisations in Japan can be considered not as an aggregation of voluntary work, but as the continuous operation of business, and entities for carrying out management for the following reasons: only a small number of organisations have no financial resources, half of ABM organisations have an administrative office; most have a long history, and a large portion carry out activities more than once a month.

It could be concluded that the outcomes for ABM are diverse and generally highly valued since nine categories of effects are assessed as positive at 90 to $40 \%$. Moreover, since approximately half of ABM organisations have a spillover effect and half of the answers stated that ABM organisations have a motivating effect on others, it can be said that $\mathrm{ABM}$ is not only a common-interest activity for members, but also has an external effect - a typical example of which is the effect on the outside area with enhanced visitor numbers, a suitable or beautiful landscape, etc. In addition, the effect of enhanced visitor numbers easily facilitates a spillover effect.

Approximately half of $\mathrm{ABM}$ organisations have problems and many point towards issues concerning finance or human resources.

Finally, with certain objectives mainly focusing on enhancing visitor numbers, creating a beautiful landscape, and enhancing community power, despite facing a variety of problems involving the local community, quality of life, and economics, ABM in Japan can be characterised as a continuous management process for carrying out various activities in different regions. This process depends on the particular situation in each area, managed by a large variety of organisations with different corporate forms, administrative office positions, and income sources.

\section{Acknowledgments}

The authors would like to express their grateful thanks to Shigenori Kobayashi, professor emeritus at Yokohama National University; Motohiro Adachi, professor at Wakayama University; other members of the City and Town Management by Public-Private Partnerships research workshop; Masato Yodo, associate professor at the Institute of Economic Research, Kyoto University; Yusuke Kobayashi, former researcher of the Graduate School of Management, Kyoto University and other secretariats of the workshop; and Kazumasa Hirao, former office assistant at the Graduate School of Management, Kyoto University and other students involved in the workshop. In addition,we would also like to acknowledge the assistance of the co-organiser for $\mathrm{ABM}$ questionnaire 
participants, namely the Urban Renewal Promotion Division, City Bureau, Ministry of Land, Infrastructure, Transport and Tourism, Japan; the Faculty of Economics, Wakayama University, the data coordinator for the ABM questionnaires, Yusuke Horie, other staff from SHOWA Corporation, and all $\mathrm{ABM}$ questionnaire respondents.

\section{References}

Asai T, Morita K, Uchiumi M, Kobayashi S, Nam J (2002) Study of Realities in the Area Management in the Core Areas of Large Cities. Papers on City Planning 37: 601606. The City Planning Institute of Japan. [in Japanese].

British BIDs (2016) Nationwide BID survey 2016, New York city small business services fiscal year 2014 business improvement districts trends report. Retrieved from https://on.nyc.gov/2qjJIGl. [Accessed May 2017].

Cho S, Deguchi A (2009) Roles of area management organization in planning and management of city center. Journal of Architecture and Urban Design, Kyushu University 15: 1-7. Faculty of Human-Environment Studies, Kyushu University. [in Japanese].

Fukuoka H, Murata Y, Aoi T, Taji T (2008) Activities and organization of area management in the Tokyo metropolitan area. Memoirs of the Institute of Science and Technology, Meiji University 47(2): 31-45. Memoirs of the Institute of Science and Technology, Meiji University. [in Japanese].

Hirao K, Mitarai J (2017) A study on organizations, academic researches and supporting systems of area based management in Japan. Regional management studies: the Journal of the Association for Regional Management in Japan 2: 85-95. Association for Regional Management in Japan. [in Japanese].

Izumiyama R, Kobayashi M (2013) Study on Urban Renewal Corporation System promotes development from the point of view of the local city type of area management; Possibilities and challenges of securing business revenue and the use of public space due to urban development company. Summaries of technical papers of Annual Meeting Architectural Institute of Japan 2013: 827-830. [in Japanese].

Izumiyama R (2015) A study on the Area Based Management with a focus on application of Public Place; Consideration by visualization analysis of business model and reviewing process of Area Based Management. Doctoral thesis, Graduate School of Science and Technology, Meiji University. [in Japanese].

Izumiyama R, Akiyama H, Kobayashi $M$ (2015) Study on the Application and Management of Privately Owned Public Spaces in the Urban Central Area Through research and analysis to community management organization registration system the Tokyo Municipal Ordinance on promoting the creation Syareta-Machinami of Tokyo. Journal of Architecture, Planning and Environmental Engineering 80(710): 915-922. Architectural Institute of Japan. [in Japanese].

Kinoshita H, Yasui M (2012) Challenges in district management in Japanese city centres: Establishing independent business models using local resources. Journal of Urban Regeneration and Renewal 6(3): 264-277.

Kobayashi S (2005) Area management-Chiku soshiki niyoru keikaku to kanriunei (Area management-Management and plan by an area organization). Kyoto: Gakugei publishing. [in Japanese].

Lee S, Kobayashi S (2004) A Study on the Processing of Area Management Activities in the Core Area of Large Cities.Case Study of Otemachi Marunouchi Yurakucho 
(Daimaruyu). City planning review. Special issue, Papers on city planning 39: 745750. The City Planning Institute of Japan. [in Japanese].

Lee S, Kobayashi S (2005) A Study on Area Management Organizations by Regional Type in the Core Area of Large Cities; With Emphasis on Organization Characteristics and its Cooperation and Network. Papers on city planning 40(3): 481486. The City Planning Institute of Japan. [in Japanese].

Ministry of Finance, Japan (2017). Japanese Government BondsMonthly Newsletter. Retrieved from https://bit.ly/2HqVi9G. [Accessed March 2017].

Ministry of Health, Labour and Welfare, Japan (2015) Annual Health, Labour and Welfare Report: Overview of the system and basic statistics 1 general welfare and labour. Retrieved from https://bit.ly/2GJXrAi. [Accessed March 2018].

Mitarai J, Suebsuk N (2016) The comparative Analysis of Performance Indicators and Information Disclosure for BIDs and Area-based Management in US UK and Japan. WITransactions on Ecology and Environment; Sustainable Development and Planning VIII: 210: 25-37. UK: WIT press.

Ministry of Land, Infrastructure, Transport and Tourism, Japan (2015) Present Systems and Projects concerning Parks and Green Spaces. Retrieved from https://bit.ly/ 2qkeSMQ. [Accessed May 2017].

Saitou H (2003) The study on possibility and issues to introduce HOA. Urban Housing Sciences 43: 156-161. Association of Urban Housing Sciences. [in Japanese].

Saito A, Yokouchi N, Okada T, Takagi M (2009) A Study on the Area Management in Urban Areas, Focused on the Activity Fiscal System of the Area Management. Summaries of Technical Papers of Annual Meeting Architectural Institute of Japan. F-1, Urban Planning, Building Economics and Housing Problems, 1125-1126. Architectural Institute of Japan. [ In Japanese].

Saitou H (2010) Problems and roles of developers of detached housing areas for management of living environment at he beginning of management period. Papers on City Planning 45(3): 769-774. The City Planning Institute of Japan. [in Japanese].

Small Business Services (SBS), New York City (NYC) (2015) Fiscal year 2015 Business Improvement Districts Trends Report. Retrieved from https://on.nyc.gov/2v0gc Kz. [Accessed May 2017].

Sorenzen A, Koizumi H, Miyamoto A (2009) Machizukuri, Civil Society, and Community Space in Japan. The Politics of Civic Space in Asia: Building Urban Communities: 33-50. New York: Rouledge Contemporary Asia Series.

The World Bank, GDP growth (2018) World Bank national accounts data, and OECD national accounts data files. Retrieved from https://bit.ly/1lRakVX. [Accessed March 2018].

Tenmyo C, Kobayashi S (2006) A Study on the Tokyo Municipal Ordinance on Promoting the Syareta-Machinamidukuri, the Creating of an Attractive and Exceptional City; The Active Usage of Public Space for the Effective Area Management, City planning review. Special Issue, Papers on City Planning 41(3): 331-336. The City Planning Institute of Japan. [in Japanese].

Ueno M, Adachi M, Mitarai J (2017) Self-Assessed Positive Impact of Area Management Organizations in Japan. The International Real Estate Review 20 (2): 189-205.

Watanabe K, Arita T (2016) Study on the process of developing self-sustaining Area Management organizations in residential areas initiated by localcommunities. Papers on City Planning 51(3): 222-229. The City Planning Institute of Japan. [in Japanese]. 
